WOJCIECH KRIEGSEISEN

https://orcid.org/0000-0001-8748-4711

The Tadeusz Manteuffel Institute of History

of the Polish Academy of Sciences, Warsaw

\title{
PROTESTANT PROVIDENTIALISM \\ IN THE COMMONWEALTH OF THE NOBLES: A CRITICAL VIEW ON SARMATISM
}

\begin{abstract}
This study is devoted to providentialism, an element characteristic of Sarmatism - a dominant ideology and culture in the early modern Commonwealth of the nobles. The attachment of special weight to providence's care of the state and the nobility seems to have been characteristic also of Protestant circles in the sixteenth and early seventeenth century, and therefore the culture of the nobles' Sarmatism should not be reduced to its late form, dominated as it was by Catholicism in the late seventeenth and eighteenth centuries.

Key w or ds: providentialism, Protestantism, Sarmatism, Catholicism, ideology of the nobility, culture of the nobility.
\end{abstract}

The explanation of the objectives and assumptions of any study should start with terminology. Thus I begin with a few words about Sarmatism as an ethnogenetic myth, according to which the Polish nobility descended from the ancient Sarmatians; and about the ideology of the nobility as an estate, which was reflected in the literary, political and religious culture; in art, customs, and even fashion in the early modern Polish-Lithuanian Commonwealth.

Despite the fact that research into and discussions about the topic constituted some of the most important themes in Polish humanities in the second half of the twentieth century, and the fact that in the early twenty-first century there emerged a glossary of concepts and symbols associated with the subject matter, ${ }^{1}$ basic questions continue to be debated. Suffice it to mention that although classic studies into the topic

\footnotetext{
${ }^{1}$ Słownik sarmatyzmu: Idee, pojęcia, symbole, ed. Andrzej Borowski, Cracow, 2001.
} 
did establish the origins of the Sarmatian myth, ${ }^{2}$ we still have problems with the chronology of the evolution and transformations of Sarmatism as an ideology of the nobility. Janusz Tazbir has proposed that the history of Sarmatism be divided into three periods: development until the mid-seventeenth century; the height of its influence in the second half of the seventeenth century; and its decline in the first half of the eighteenth century. ${ }^{3}$ Like all other periodizations, this one too is debatable, with the most controversial being the question of whether Sarmatism as an ideology was alive throughout the sixteenth century, or whether it evolved from a "learned", ethnogenetic myth to an ideology of a social group only towards the end of that century? ${ }^{4}$ How was the evolution of this ideology - which in the sixteenth century was an element uniting the nobility as an estate in the Polish-Lithuanian Commonwealth - influenced by the transformations in confessional relations? Questions like these are innumerable.

In recent years opinions have been voiced challenging the previous approach to research into Sarmatism - here I have in mind primarily Jakub Niedźwiedź's inspiring contribution. ${ }^{5}$ In referring, somewhat provocatively, to the concept of 'invented tradition' ${ }^{6}-$ a concept very popular in research into the origins of modern national consciousness since the 1980s - Niedźwiedź concludes that Sarmatism is a tradition 'invented' by the Polish Romantics in the nineteenth century. In his view historians of culture, literature and customs studying the subject matter in the twentieth century often continue to see it from the perspective defined by the Romantic eulogists of the old tradition of the Polish nobility, as well as from the perspective of its Enlightenment-era critics, who invented and

${ }^{2}$ Tadeusz Mańkowski, Genealogia sarmatyzmu, Warsaw, 1946; Tadeusz Ulewicz, Sarmacja: Studium z problematyki słowiańskiej XV i XVI w., Cracow, 1950; idem, Sarmacja: Studium z problematyki słowiańskiej XV i XVI w.: Zagadnienia sarmatyzmu w kulturze i literaturze polskiej (problematyka ogólna i zarys historyczny), Cracow, 2006, Biblioteka Tradycji, vol. 46; Stanisław Cynarski, 'Sarmatyzm - ideologia i styl życia', in Polska XVII wieku: Państwo, społeczeństwo, kultura, ed. Janusz Tazbir, Warsaw, 1969, pp. 220-43.

${ }^{3}$ Janusz Tazbir, 'Sarmatyzm a barok', KH, 76, 1969, 4, pp. 815-30.

${ }^{4}$ Tadeusz Chrzanowski, 'Sarmatyzm - mity dawne i współczesne', in idem, Wędrówki po Sarmacji europejskiej: Eseje o sztuce i kulturze staropolskiej, Cracow, 1988, pp. 7-29.

${ }^{5}$ Jakub Niedźwiedź, 'Sarmatyzm, czyli tradycja wynaleziona', Teksty Drugie, 2015, 1, pp. 46-62.

${ }^{6}$ For more on 'invented' communities and traditions, see Benedict Anderson, Imagined Communities: Reflections on the Origin and Spread of Nationalism, London, 1983; The Invention of Tradition, ed. Eric Hobsbawm and Terence Ranger, Cambridge, 1983; Polish edition Tradycja wynaleziona, ed. Eric Hobsbawm and Terence Ranger, transl. Mieczysław Godyń and Filip Godyń, Cracow, 2008. 
popularized the initially unequivocally negative terms 'Sarmatism' and 'Sarmatians'.

Journalistic and literary discussions about Sarmatism and its significance to Polish culture - quite often dominated by politics and worldview-related prejudices - are still marked by the belief that the concept of a 'Sarmatian' political and cultural formation was a unique phenomenon in Europe. ${ }^{7}$ However, such an opinion seems contrary to the results of modern research, and it has already been effectively challenged, at least with regard to the political system, by Adam Manikowski. ${ }^{8}$

As Jakub Niedźwiedź convincingly argues, traditional reflection on the culture of the "land of the winged horsemen' ${ }^{9}$ is facilitated by a unique brand of reductionism, that is an omission of phenomena different from or competing with the clichés of Sarmatism; like for example the ethnogenetic myth that the Lithuanians came from the legendary Palemon; from old Ruthenian traditions that were very much alive in Ukraine; or from German traditions cultivated by the inhabitants of Royal Prussia and Livonia; not to mention the bourgeois, peasants and Jews, who were excluded from the Sarmatian heritage. ${ }^{10}$

An important element of 'Sarmatian' culture in the multi-denominational society of the Polish-Lithuanian Commonwealth was religion, although reflections on this topic are usually restricted to Baroque Catholic

7 The belief in the unique features of old Polish culture was consolidated by the studies of earlier Polish historians of culture, beginning with Stanisław Kot's study 'Polska złotego wieku wobec kultury zachodniej', in idem, Polska złotego wieku a Europa: Studia i szkice, ed. Henryk Barycz, Warsaw, 1987, pp. 122-95 (edition princeps Cracow, 1932). For more on the contemporary apologists of the culture of Sarmatism, see Agata Wdowik, 'Poszukiwania własnych korzeni - rzecz o tekstach Krzysztofa Koehlera (oraz Andrzeja Waśki)', in Nowoczesność i sarmatyzm, ed. Przemysław Czapliński, Poznań, 2011, pp. 231-50. Grażyna Filip and Magdalena Patro-Kucab, 'Obraz sarmatyzmu utrwalony w polskiej leksyce i przestrzeni społecznej - wybrane zagadnienia i przykłady', Słowo: Studia językoznawcze, 4, 2013, pp. 53-71.

${ }^{8}$ Adam Manikowski, 'Czy siedemnastowieczna Rzeczpospolita była anomalią wśród innych państw europejskich?', OiRP, 37, 1993, pp. 79-87; see also Mariusz Markiewicz, “Jedyna i nieporównywalna?”: Normalne państwo europejskie, czy może państwo pogranicza?', in Między Zachodem a Wschodem: Studia z dziejów Rzeczypospolitej w epoce nowożytnej, ed. Jacek Staszewski, Krzysztof Mikulski and Jarosław Dumanowski, Toruń, 2002, pp. 17-22; Wojciech Tygielski, 'Rzeczpospolita szlachecka: paradoks historii czy europejska norma?', in Tematy polsko-białoruskie: Historia. Literatura. Edukacja, ed. Robert Traba, Olsztyn, 2003, pp. 40-53.

9 'The Land of the Winged Horsemen: Art in Poland 1572-1764' - an exhibition prepared by the Royal Castle on the Wawel Hill and the Royal Castle in Warsaw, presented in the USA in 1999/2000 and at the Royal Castle in Warsaw in 2000.

${ }^{10}$ Niedźwiedź, 'Sarmatyzm', pp. 49-52. 
religiosity. ${ }^{11}$ Many authors exploring the topic are aware of the religious diversity of the nobility in the Polish-Lithuanian Commonwealth in the sixteenth and seventeenth centuries, but in practice reflection on Sarmatian religious culture is usually focused on its Catholic aspects. ${ }^{12}$ This is why the aim of the present study is to challenge the belief in the Catholic nature of Sarmatism - a belief which is widely held in general and popular works. ${ }^{13}$

Let us now move to the problem of providentialism. There is no doubt that the belief that God took care of the commonwealth of the nobility was an important element of the ideology of Sarmatism. ${ }^{14}$ This is apparently one of the distinctive features of this culture; a culture, which, with the progress of Catholic confessionalization, became increasingly dominated by Baroque Catholicism. Strengthened in the second half of the seventeenth century by the growing Marian cult, ${ }^{15}$ the belief that providence was protecting the Commonwealth had some dangerous consequences. In the eighteenth century it led to the emergence of Sarmatian Quietism, which was not conducive to reforms designed to strengthen the state. ${ }^{16}$ This had lamentable political consequences in the second half of that century. On the other hand, when it comes to the long-term consequences in culture and mentality, Sarmatian providentialism is sometimes regarded as a factor responsible for the low level of intellectual culture in Poland, even to this day. ${ }^{17}$

${ }^{11}$ A good example of such reduction is Tadeusz Chrzanowski's otherwise interesting study, 'Sarmacka eschatologia', in idem, Wędrówki po Sarmacji europejskiej, pp. 252-83.

${ }^{12}$ See for example Janusz Tazbir, 'Sarmatyzacja katolicyzmu w XVII wieku', in Wiek XVII - kontrreformacja - barok: Prace z historii kultury, ed. Jerzy Pelc, Wrocław, 1970, pp. 7-37; idem, 'Religijność doby kontrreformacji', in idem, Szlachta i teologowie: Studia z dziejów polskiej kontrreformacji, Warsaw, 1987, pp. 217-29.

${ }^{13}$ Władysław Kopaliński, Słownik mitów i tradycji kultury, Warsaw, 1996, defines the features of Sarmatism in accordance with the Enlightenment-era formula: 'megalomania of the nation and the estate, self-admiration, contempt for and aversion to foreigners and people of other faiths, intolerance, superficial devotion combined with religious fanatism and belief in superstitions'; see also Michał Czerenkiewicz, 'Sarmaci i Opatrzność, Passage to knowledge, Museum of King Jan III’s Palace at Wilanów, $<$ https://www .wilanow-palac.pl/prowidencjalizm_sarmatow.html $\rangle$ [accessed 15 May 2020].

${ }^{14}$ Cynarski, 'Sarmatyzm', pp. 229-30; Janusz Tazbir, 'Problemy wyznaniowe', in Polska XVII wieku, pp. 189-219.

${ }^{15}$ See Katarzyna Wiktoria Szwargocka, 'Sarmacka Bogini': Kult maryjny w Polsce doby baroku, Toruń, 2010.

${ }^{16}$ Karol Górski, 'Religijność sarmatyzmu a kwietyzm', Teksty: Teoria literatury, krytyka, interpretacja, 16, 1974, 4, pp. 58-75.

${ }^{17}$ Andrzej Zybała, 'Wokół kultury umysłowej w Polsce - jej źródła i przejawy', Kultura i Społeczeństwo, 2017, 4, pp. 101-21. 
It seems appropriate to start by referring to the definition of the term 'providentialism' mentioned in the title of this study. It comes from the Latin word providentia, literally meaning foreknowledge, but which in Polish is usually rendered as opatrzność, a term with no such associations. In philosophy and theology it denotes a belief according to which the fate of the world is governed by a higher power or providence (usually divine providence). According to the theistic Christian interpretation, the Creator of the universe freely and fully controls everything going on in it. ${ }^{18}$ Under this doctrine, the history of the world and humankind is part of providence's plan and through it God pursues his intentions - unfathomable to mere mortals, but undoubtedly having their salvation as their purpose. Yet adoption of this concept could result in people descending into determinism, and attempts to avoid this trap since the time of Augustine of Hippo and the Pelagian controversy sparked discussions about free will, grace, and eventually predestination. ${ }^{19}$

It would also be a truism to say that the belief in divine intervention in the fate of the world has been present in cultural texts since ancient times; here one may mention only the oldest and best known authors, that

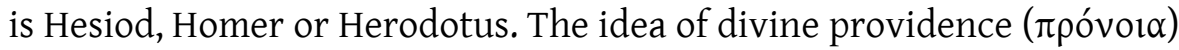
was formulated by ancient philosophers, from Socrates and Plato to the stoics, including the best known among them, Seneca. ${ }^{20}$ In early Christian philosophy and theology the notion of providence, firmly established already by Origen and the Greek Church Fathers, ${ }^{21}$ was developed by

${ }^{18}$ Herbert Jedin, 'Vorsehung', in Lexikon für Theologie und Kirche, ed. Michael Buchberger, 10 vols, Freiburg im Breisgau, 1930-38, vol. 10, 1938; Hugh J. McCann and Daniel M. Johnson, 'Divine Providence', in The Stanford Encyclopedia of Philosophy (spring 2017), ed. Edward N. Zalta, <https://plato.stanford.edu/archives/spr2017/ entries/providence-divine/ $>$ [accessed 16 May 2020].

${ }^{19}$ See S. Aurelii Augustini, De dono perseverantiae liber unus. Liber ad Prosperum et Hilarium secundus, in idem, Opera omnia, PL, vol. 45, 〈http://www.augustinus.it > [accessed 17 March 2021]; Polish translation: idem, Dar wytrwania, do Prospera i Hilarego, transl. Wacław Eborowicz, in Łaska, wiara, przeznaczenie, ed. Wacław Eborowicz, Poznań, 1971, pp. 335-85; see Réginald Garrigou-Lagrange OP, 'La prédestination d'après les pères latins, particulièrement d'après saint Augustin', in Dictionnaire de Théologie Catholique, ed. Jean M.A. Vacant, Eugène Mangenot and Émile Amann, 15 vols, Paris, 1902-50, vol. 12, part 2, 1935, cols 2832-2901, <http://jesusmarie.free.fr/dictionnaire_ de_theologie_catholique.html $\rangle$ [accessed 17 March 2021].

${ }^{20}$ See Lucjusz Anneusz Seneca, 'O opatrzności (De Providentia)', in idem, Myśli, bilingual edition, trans. and ed. Stanisław Stabryła, Cracow, 1987, pp. 36-51. Rafał Marcin Leszczyński, Starożytna koncepcja Logosu i jej wpływ na myśl wczesnego chrześcijaństwa, Warsaw, 2004.

${ }^{21}$ Tomasz Stępień, ‘Filozoficzne podstawy rozumienia opatrzności u greckich Ojców Kościoła', Warszawskie Studia Teologiczne, 14, 2001, pp. 97-114. 
St Augustine ${ }^{22}$ and his thought was continued by theologians in late Antiquity and the Middle Ages. It was given doctrinal shape by Thomas Aquinas, who used the apparatus of scholastic distinctions to reconcile the doctrine of divine providence with the dogma of free will. ${ }^{23}$ Compatibilist theses, according to which there was no contradiction between the two, were justified by the assertion that the general principle of divine omnipotence was always superordinate to the particular circumstances stemming from human free will. ${ }^{24}$ In the early modern period this doctrine would become an obligatory part of Catholic teaching. ${ }^{25}$

The belief in the existence of some providence controlling the affairs of both the world and of individuals was central to medieval culture and historiography. Yet studies of Polish sermons from that era have indicated that a lack of appropriate terminology led to considerable simplifications in the doctrine of providence in medieval Poland. ${ }^{26}$ This was facilitated by the popular doctrine of guardian angels, who as tools of providence would look after every human being from his or her birth. ${ }^{27}$ At the same time however, we do know that at least the Church

${ }^{22}$ Scholars usually cite two of his works devoted to the subject: S. Aurelii Augustini, De Trinitate libri quindecim, in idem, Opera omnia, PL, vol. 42, liber III, cap. 4: 'Dei voluntas utitur omnibus rebus ad incommutabile arbitrium sapientiae suae.' <http:// augustinus.it $>$ [accessed 17 March 2021], Polish translation: O Trójcy Świętej, transl. Maria Stokowska, Cracow, 1996, and idem, De diversis quaestionibus octoginta tribus, in idem, Opera omnia, PL, vol. 40, liber XXVII: De providentia 〈http://augustinus.it> [accessed 17 March 2021], Polish translation: Księga osiemdziesięciu trzech kwestii, transl. Ida Radziejowska, Kęty, 2021; see Annette Rascol, 'La providence selon saint Augustin', in Dictionnaire de Théologie Catholique, vol. 13, part 1, 1936, cols 961-84 < http://jesusmarie .free.fr/dictionnaire_de_theologie_catholique.html $\rangle$ [accessed 17 March 2021]; Juliusz Domański, 'Opatrzność Boża i wolność ludzka w filozofii św. Augustyna', Przeglad Tomistyczny, 10, 2004, pp. 7-32.

${ }^{23}$ Franciszek Bargieł, 'Opatrzność Boża a zło według św. Augustyna i św. Tomasza', Rocznik Wydziału Filozoficznego Wyższej Szkoły Filozoficzno-Pedagogicznej 'Ignatianum' w Krakowie, 11, 2004/05, pp. 113-43; Marek Jędraszewski, 'Opatrzność Boża w świetle filozofii', Studia Theologica Varsaviensia, 48, 2010, 2, pp. 63-91; Matthew Levering, 'Eternity, History, and Divine Providence', Angelicum, 88, 2011, 2, pp. 403-23.

${ }^{24}$ S. Thomae de Aquino, Summa Theologiae, pars 1, quaestio 19, art. 6; ibid., quaestio 23, art. 3, 〈http://corpusthomisticum.org > [accessed 20 May 2020]; Polish translation: Św. Tomasz, Suma teologiczna, vol. 2, transl. and ed. Pius Bełch OP, 34 vols, London, 1962-86, vol. 2, [1977].

${ }^{25}$ Réginald Garrigou-Lagrange OP, 'La providence selon la théologie', in Dictionnaire de Théologie Catholique, vol. 13, part 1, cols 985-1023, <http://jesusmarie.free.fr/ dictionnaire_de_theologie_catholique.html $\rangle$ [accessed 17 March 2021].

${ }^{26}$ Krzysztof Bracha, 'Spectabilis - opactrnoszcz: Oczy Pana w nauczaniu kaznodziejskim w Polsce późnego średniowiecza', in Staropolski oglad świata: Sarmacki sensualizm, red. Filip Wolański, Toruń, 2017, pp. 11-22.

${ }^{27}$ Wojciech Brojer, 'Anioł w wyobraźni chrześcijan do XIII wieku', in Wyobraźnia średniowieczna, ed. Teresa Michałowska, Warsaw, 1996, pp. 155-76. 
elites in medieval Poland were aware of the meaning of providentialism in its deepest sense, in which God appeared as the 'lord of history'. According to Jan Długosz, 'Providence is a force controlling the fate of human beings and the world, and through events in history God carries out his own plans and decisions. ${ }^{28}$

But towards the end of the sixteenth century the Counter-Reformation took up and developed concepts of providence that were adapted to the popular imagination, if not to say naive. ${ }^{29}$ Thus emphasis was placed on the incidental, interventionist as it were, nature of its operation; there also emerged the belief in God's special protection of the Commonwealth, a process that became more intense after the crisis caused by the mid-seventeenth-century wars and was further enhanced by the bulwark theory, which bordered on Messianism. ${ }^{30}$ In 1656 John Casimir's Lviv Oath, in which the Virgin Mary was proclaimed Queen of the Polish Crown, strengthened popular Marian providentialism as well. In the light of research carried out by Janusz Tazbir and his continuators, there is no doubt that at least from the mid-seventeenth century Catholic teaching, especially elements addressed 'to the people', increasingly albeit counter to political reality at the time - supported an optimistic vision of the fate of the Polish-Lithuanian Commonwealth as a country under the special protection of providence. ${ }^{31}$

The man regarded as the most outstanding representative of the providentialist strand in the Polish literature of that era is Wespazjan Kochowski. $^{32}$ However, even a perfunctory overview of his oeuvres as well as those of other writers active in the Polish-Lithuanian Commonwealth in the seventeenth and eighteenth centuries, especially those dealing with history, shows that 'Sarmatian' providentialism was an integral element of their world view. One should mention here Szymon Starowolski, a canon in Cracow; Jan Białobocki, secretary to King Władysław IV; Andrzej Olszowski, Archbishop of Gniezno; and Kazimierz Zawadzki, Castellan of Chełmno, who in his Historia arcana argued that the most convincing proof of divine providence acting for the benefit of the Polish-Lithuanian Commonwealth

${ }^{28}$ Adam Talarowski, 'Dzieje w rękach Opatrzności: Elementy historiozofii Jana Długosza i jej uwarunkowania', $R H, 84,2018$, pp. 191-225.

${ }^{29}$ Paul V (d. 1621) established the Memorial of the Guardian Angels on 2 October.

${ }^{30}$ Janusz Tazbir, Polska przedmurzem Europy, Warsaw, 2004.

${ }^{31}$ Tazbir, 'Sarmatyzm', p. 82; idem 'Ze studiów nad ksenofobią w Polsce w dobie późnego renesansu', PH, 48, 1957, 4, pp. 655-82; idem, 'Wizje przyszłości w kulturze staropolskiej', OiRP, 27, 1982, pp. 107-41 (p. 139).

${ }^{32}$ Hans-Jürgen Bömelburg, Polska myśl historyczna a humanistyczna historia narodowa (1500-1700), transl. Zdzisław Owczarek, introduction Andreas Lawaty, ed. Maciej Ptaszyński, Cracow, 2011, pp. 458-63. 
was the election of Michał Korybut Wiśniowiecki. ${ }^{33}$ Finally, one should also mention some eighteenth-century writers - such as Augustyn Kołudzki, a district judge in Inowrocław; Father Gaudenty Pikulski OFM Ref.; Władysław Aleksander Łubieński, Archbishop of Gniezno, and last but not least, Father Szymon Majchrowicz SJ. ${ }^{34}$

A special place among Polish authors who adhered to providentialism in their reflections on the fate of the Commonwealth obviously belongs to Wojciech Dembołęcki, doctor of sacred theology, OFM Conv. who as early as in 1633 published the 'arch-Sarmatian' Wywód jedynowładnego państwa świata (A Disquisition on the Only Sovereign State in the World). In it he claimed, for example, that Poles were the oldest and finest people on earth, and by God's will they deserve to be put above other, inferior peoples. These reflections are an example of an aberrational Sarmatian megalomania stemming from a primitively understood doctrine of providence and Messianic tendencies. ${ }^{35}$

A question that should be asked at this point is: Was providentialism a differentia specifica of 'Sarmatian' writings in Europe? In his study of Polish thought from the sixteenth and seventeenth centuries, Hans-Jürgen Bömelburg notes that 'a humanistic vision of history with confessional and providentialist elements as well as elements of the history of salvation was a common phenomenon in Europe. ${ }^{36}$ The German historian sees par-

${ }^{33}$ Kazimierz Zawadzki, Historia arcana, seu annalium polonicorum libri VII. Reductae primum et post Piasti tempora vere liberi voti liberae electionis, centuriatis Regni comitiis in electorali campo celebratae, Frankfurt am Main, 1699, p. 38; see Bömelburg, Polska myśl historyczna, p. 453, note 14.

${ }^{34}$ Kazimierz Bartkiewicz, Obraz dziejów ojczystych w świadomości historycznej w Polsce doby oświecenia, Lublin, 1979, p. 18; Dariusz Dolański, Zachód w polskiej myśli historycznej czasów saskich: Nurt sarmacko-teologiczny, Zielona Góra, 2002, p. 118 f.; Bömelburg, Polska myśl historyczna, pp. 502-16; Robert Buczak, 'Kontrowersje i ponadczasowy wydźwięk legendy "rokoszu gliniańskiego” w sarmackiej wizji dziejów Augustyna Kołudzkiego’, In Gremium: Studia nad historia, kultura i polityka, 2, 2008, pp. 45-59; Stanisław Grzybowski, 'Z dziejów popularyzacji nauki w czasach saskich: Spóźniona synteza księdza Szymona Majchrowicza', in Studia i Materiały z Dziejów Nauki Polskiej, ser. A, no. 7, 1965, pp. 133-45; see Piotr Sebastian Ślusarczyk, 'Między traktatem historycznym a publicystyką: Studium o "Trwałości szczęśliwej królestw” Szymona Majchrowicza', doctoral dissertation, supervisor Roman Krzywy, Institute of Polish Literature, Faculty of Polish Studies, University of Warsaw, 2013, 〈http://depotuw.ceon.pl〉 [accessed 17 May 2020].

${ }^{35}$ Radosław Sztyber, 'Skądże to zbłaźnienie świata?': Wojciecha Dembołęckiego 'Wywód jedynowładnego państwa świata' (studium monograficzne i edycja krytyczna dzieła), Zielona Góra, 2012; Zbigniew Ogonowski, 'Z dziejów megalomanii narodowej', in idem, Filozofia polityczna w Polsce XVII wieku i tradycje demokracji europejskiej, Warsaw, 1992, pp. 157-73; Piotr Czarczyński, "Między "święta prawdą" a herezją - Biblia w Wywodzie jedynowładnego państwa świata Wojciecha Dembołęckiego', Tematy i Konteksty, 11, 2016, 6, pp. 125-39.

${ }^{36}$ Bömelburg, Polska myśl historyczna, p. 515; a good analogy for Sarmatism is pro- 
allels in the development of tendencies - inspired by a common source to think in terms of Catholic providentialism in France, Italy, and the Polish-Lithuanian Commonwealth. Bömelburg even suggests that Jacques-Bénigne Bossuet's historical-religious concepts formulated in 1679 in the treatise Discours sur l'histoire universelle were embraced and exerted their influence in Poland and the Grand Duchy of Lithuania through the works of Jesuit historian Giovanni Domenico Musanti. ${ }^{37}$

But perhaps not only providentialism, but also the intense Marian cult and the belief that the Queen of the Polish Crown protected the Commonwealth of the nobility in a special way ${ }^{38}$ - commonly regarded as distinctive features of Sarmatism - were not an original product of Polish culture. Damien Tricoire's research shows that both entrusting the Commonwealth to the care of the Virgin Mary in 1656, and then the special public and private veneration of the Madonna were not an original Polish invention; instead, they imitated earlier models: Bavarian, Austrian (pietas austriaca) as well as French models of Catholic piety from Louis XIII's times. ${ }^{39}$

What remains outside the scope of Tricoire's study is, obviously, Romantic providentialism, which was even more important to the emergence of modern paradigms of Polish culture; in which God's influence on history determined the boundaries of independent human action. There is no need to go on at length about the significance of this worldview - which strengthened the belief in providence's individual and incidental operation - in Polish culture of the nineteenth and twentieth centuries. $^{40}$

vided by the ideology of Dutch Batavism; see Antoni Ziemba, Nowe dzieci Izraela: Stary Testament $w$ kulturze holenderskiej XVII wieku, Warsaw, 2000.

${ }^{37}$ Bömelburg, Polska myśl historyczna, pp. 115-18; Patrick J. Barry, 'Discourse on Universal History', The Catholic Historical Review, 20, 1934, 3, pp. 260-80. One of Musanti's main works, Fax chronologica ad omnigenam historiam et dilucidum eiusdem compendium ab orbe condido ad annum Christi 1712, was published by the Jesuit printing shop only in 1724, but numerous foreign editions may have been used earlier.

${ }^{38}$ Hans-Jürgen Bömelburg, 'Maria als Garantin nationaler Freiheit in Polen: Ein typologischer Sonderfall des Marienpatronats in einer partizipativen Adelsgesellschaft', in Maria in der Krise: Kultpraxis zwischen Konfession und Politik in Ostmitteleuropa, ed. Agnieszka Gąsior, Cologne, 2014, pp. 79-92, Visuelle Geschichtskultur, vol. 10.

${ }^{39}$ Damien Tricoire, 'Gottesmutter Königin von Polen: Die Sakralisierung der polnischen Monarchie im Vergleich mit Frankreich und Bayern (1630er-1650er Jahre)', in Maria in der Krise, pp. 93-116; idem, La Vierge et le Roi: Politique princière et imaginaire catholique dans l'Europe du XVII siècle, Paris, 2017.

${ }^{40}$ Józef Ujejski, Dzieje polskiego mesjanizmu do powstania listopadowego włącznie, Lviv, 1931. 
It should also be clearly stressed that providentialist ideas were not unique to early modern Catholic culture. They were very much alive in non-Catholic communities, such as, for example Protestant communities in the Northern Netherlands. This is hardly surprising, given the fact that they were rooted in the dogmatic theology of the Lutheran and Reformed Churches, and even in the symbolic books of both denominations. ${ }^{41}$ The doctrine of divine providence is linked to the doctrine - interpreted in a variety of ways but derived straight from the theology of St Augustine of grace and predestination.

Because of this link the matter was particularly important to the Calvinists. It was explored already by the 'founding fathers' of this strand of Protestant theology, that is Huldrych Zwingli and John Calvin. ${ }^{42}$ In 1530 Zwingli even published a philosophical treatise devoted to providence and dedicated it to Philip the Magnanimous, Landgrave of Hesse. ${ }^{43}$ On the other hand Calvin, who in his philosophical concepts referred to the stoics and Cicero, ${ }^{44}$ discussed theological views on providence in his Institutio christianae religionis (Book I, Chapters 16 and 17 according to the 1559 edition). The title of Chapter 16 was 'Deum sua virtute mundum a se conditum fovere ac tueri, et singulas eius partes sua providentia regere', and Calvin developed the idea in Paragraphs 3 and 4, where he claimed that everything in the world proceeded according to God's mysterious plan and nothing could happen without God's free and conscious decision. ${ }^{45}$

${ }^{41}$ Formula concordiae 1577, art. 'O wiecznej opaczności i wyborze Bożym', in Formuła zgody z 1577 roku, transl. Józef Pośpiech, Bielsko-Biała, 2003, p. 72; Konfesja, albo wyznanie wiary powszechnej kościołów chrześcijańskich polskich z roku 1570, art. 6 'O Opatrzności Bożej’, in Konfesja sandomierska, ed. Krystyna Długosz-Kurczabowa, Warsaw, 1995, pp. 53-57.

${ }^{42}$ Paul Helm, 'Calvin (and Zwingli) on Divine Providence', Calvin Theological Journal, 29, 1994, 2, pp. 388-405.

${ }^{43}$ Huldrych Zwingli, 'Ad illustrissimum Cattorum principem Philippum, sermonis de providentia Dei anamnema', in idem, Opera completa editio prima, 8 vols, ed. Melchior Schuler and Johannes Schulthess, Zürich, 1829-42, vol. 4: Latinorum scriptorum pars secunda, 1841, pp. 79-144, (editio princeps 1530), partial translation into Polish: Huldrych Zwingli, 'O Opatrzności Bożej’, transl. Juliusz Domański, in Myśl filozoficzno-religijna Reformacji XVI wieku, ed. Lech Szczucki, Warsaw, 1972, pp. 106-67; see Rafał Marcin Leszczyński, 'Ulrych Zwingli a filozofia', Rocznik Teologiczny, 62, 2020, 2, pp. 463-90.

${ }^{44}$ Rafał Marcin Leszczyński, ‘Cyceroniańskie wątki w Institutio Christianae religionis Jana Kalwina', in idem, Jan Kalwin: Studia nad myśla Reformatora, Warsaw, 2017, pp. 29-61.

${ }^{45}$ Ioannis Calvini Institutio christianae religionis, ed. August Tholuck, pars 1, Berlin, 1846, pp. 134-43; Polish translation: 'O tym, że Bóg wspiera świat stworzony jego mocą i opiekuje się nim, a jego poszczególnymi częściami rządzi opatrznościowo’, in Jan Kalwin, Istota religii chrześcijańskiej. Institutio christianae religionis, księga pierwsza, transl. Janusz Kucharczyk et al., Świętochłowice, 2020, pp. 289-306; Callie F.C. Coetzee, 'The 
He may have been polemicizing here with the Catholic interpretation, established by Thomas Aquinas, [see below] of predestination as stemming from God's prescience or foreknowledge (praescientia) concerning human behaviour, by contrasting the 'reactive' Catholic idea of providence with the concept of the divine plan of salvation, which provided for active control of the fate of creation and under which decisions stemmed from God's sovereign will (albeit mysterious when it came to its causes). ${ }^{46}$ In $1557-58$ Calvin also published two polemical treatises in which he argued, for example, that divine providence should be understood individually, which meant that every creature and all of creation were its object. ${ }^{47}$

Such a doctrine of providence was accepted far beyond Geneva. It was followed by the Scottish reformer John Knox, by the English Puritans, and even by the Anglicans. ${ }^{48}$ Intense Puritan providentialism played a huge role in the England of Cromwell's era ${ }^{49}$ and its later importance in the history of Anglo-Saxon culture can hardly be overestimated.$^{50}$ A special role in English religious culture, as well as political and literary culture, was played by the theology of a covenant between God and his people, a theology genetically linked to the doctrine of providence. Initially formulated in Zurich by Heinrich Bullinger (the author of Confessio helvetica posterior, the basis of the Sandomierz Confession) and the Heidelberg theologian

Doctrine of Providence in the Institutes of Calvin - Still Relevant?', In die Skriflig/In Luce Verbi, 44, 2010, Supplement 3, pp. 145-66.

${ }^{46}$ I. John Hesselink, 'Calvin's Theology', in The Cambridge Companion to John Calvin, ed. Donald K. McKim, Cambridge, 2006, pp. 74-92 (p. 85).

47 Brevis responsio Io. Calvini ad diluendas nebulonis cuiusdam calumnias quibus doctrinam de aeterna Dei praedestinatione foedare conatus est (1557), in Joannis Calvini opera quae supersunt omnia, 59 vols, ed. Eduard Cunitz, Johann-Wilhelm Baum and Eduard Wilhelm Eugen Reuss, Braunschweig, 1863-1900, vol. 9, 1870, pp. 253-66; Calumniae nebulonis cuiusdam, quibus odio et invidia gravare conatus est doctrinam Ioh. Calvini de occulta Dei providentia (1558), in ibid., pp. 268-318.

${ }^{48}$ Richard Kyle, 'John Knox's Concept of Divine Providence and Its Influence on His Thought', Albion: A Quarterly Journal Concerned with British Studies, 18, 1986, 3, pp. 395-410; Alexandra Walsham, 'Providence, Print, and the Religion of Protestants', in eadem, Providence in Early Modern England, Oxford, 1999, pp. 8-64.

${ }^{49}$ Blair Worden, 'Providence and Politics in Cromwellian England', P\&P, 109, 1985, pp. 55-99; David Randall, 'Providence, Fortune, and the Experience of Combat: English Printed Battlefield Reports, Circa 1570-1637', Sixteenth Century Journal, 35, 2004, 4, pp. 1053-77; George Drake, 'The Ideology of Oliver Cromwell', Church History, 35, 1966, 3, pp. 259-72.

${ }^{50}$ Michael P. Winship, Seers of God: Puritan Providentialism in the Restoration and Early Enlightenment, Baltimore, MD: John Hopkins University Press, 1996; Michael Finlayson, 'Clarendon, Providence and the Historical Revolution', Albion: A Quarterly Journal Concerned with British Studies, 22, 1990, 4, pp.607-32; Alexandra Walsham, 'History, Memory, and the English Reformation', HJ, 55, 2012, 4, pp. 899-938. 
Zacharias Ursinus, ${ }^{51}$ in the seventeenth century it became one of the most important topics in Protestant theological literature, not only in England but also across Europe. ${ }^{52}$

Interest in providentialism, and specifically in covenant theology (verbondsleer), was strong among the Dutch Calvinists. ${ }^{53}$ This is important in terms of findings concerning the providentialist views of members of the Reformed Church in the Polish-Lithuanian Commonwealth, because future ministers in the Crown and the Grand Duchy of Lithuania often studied at Dutch universities (Leiden, Franeker, Groningen). From the late sixteenth century providentialism was studied and taught by the most eminent Protestant theologians in the Netherlands. Suffice it to say that the doctrine of providence was studied at Leiden University by Franciscus Gomarus and Jacobus Arminius, two outstanding theologians representing competing tendencies in the Reformed Church in the Northern Netherlands. ${ }^{54}$

Covenant theology, associated with the doctrine of providence, was also studied at universities in the Northern Netherlands. Its most distinguished advocates include Frans Burman (1628-79), professor at Utrecht and Hermann Witsius (1636-1708), professor at Franeker, Utrecht and Leiden; but the best known - also to students from the Polish-Lithuanian Commonwealth - scholar among them was Johannes Cocceius (1603-69), a pupil of Jan Makowski (Maccovius) ${ }^{55}$ at Franeker, Frisia, and then professor at Bremen, Franeker and Leiden. ${ }^{56}$ Although in the seventeenth

${ }^{51} \mathrm{~J}$. Wayne Baker, Heinrich Bullinger and the Covenant: The Other Reformed Tradition, Athens, OH, 1980; idem, 'Heinrich Bullinger, the Covenant, and the Reformed Tradition in Retrospect', Sixteenth Century Journal, 29, 1998, 2, 359-76; Derk Visser, 'The Covenant in Zacharias Ursinus', Sixteenth Century Journal, 18, 1987, 4, pp. 531-44.

${ }^{52}$ Richard L. Greaves, 'The Origins and Early Development of English Covenant Theology', The Historian, 31, 1968, 1, pp. 21-35; Lyle D. Bierma, 'The Role of Covenant Theology in Early Reformed Orthodoxy', Sixteenth Century Journal, 21, 1990, 3, pp. 453-62.

${ }^{53}$ Ziemba, Nowe dzieci Izraela, pp.69-74; for more on the early modern history of the Reformed Church in the Northern Netherlands, see Kazimierz Bem, 'Wilki i łagodne jagniątka Chrystusa': Powstanie, rozwój i rola Holenderskiego Kościoła Reformowanego w XVI i XVII wieku, Warsaw, 2013.

${ }^{54}$ Franciscus Gomarus (lecturer at Leiden, and then Middelburg, Saumur and Groningen), Conciliatio doctrinae orthodoxae de providentia Dei, Leiden, 1597; on the views of Jacobus Arminius, see Damian Dorocki, 'Doktryna predestynacji w teologii Jakuba Arminiusza', Teologia i Człowiek: Kwartalnik Wydziału Teologicznego UAM, 35, 2016, 3, pp. 107-24; Raymond A. Blacketer, 'Arminius' concept of Covenant in its historical context', Nederlands archief voor kerkgeschiedenis, 80, 2000, 2, pp. 193-220.

${ }^{55}$ Stefan Kiedroń, 'Jan Makowski (1588-1644): Polski teolog we fryzyjskim Franekerze', OiRP, 40, 1996, pp. 37-51.

${ }^{56}$ Frans Burman, author of Synopsis theologiae et speciatim foederum Dei ab initiis saeculorum usque ad consummationem eum, Utrecht, 1671, numerous further editions and 
century the doctrine of providentialism was modified in England, Geneva, and, above all, in the Northern Netherlands, it continued to be a permanent feature in the teachings of Reformed orthodoxy. ${ }^{57}$

Polish Protestants, especially members of the Reformed Church, as well as the Unity of the Brethren and the Polish Brethren, cultivated the doctrine of divine providence and, to a lesser extent, covenant theology, drawing on the same doctrinal sources as the Swiss, the English, the Scots or the Dutch. In the sixteenth-century Polish-Lithuanian Commonwealth the most eminent representatives of the Reformed political and religious thought adhered to providentialist concepts as well. In his reflections on the fate of the Commonwealth of the nobility, Andrzej Frycz Modrzewski liked to use Old Testament references. ${ }^{58}$ Another providentialist was probably Andrzej Wolan, the most outstanding Reformed theologian in the Polish-Lithuanian Commonwealth in the sixteenth century, a follower of Modrzewski's ideas ${ }^{59}$ and a consistent Calvinist, who must have accepted the providentialist concepts of the author of Institutio christianae religionis. ${ }^{60}$

When it comes to political thought, Wolan wrote a work on civic liberty that became symptomatic of 'Renaissance Sarmatism' and was originally published in Latin as De libertate politica sive civili libellus lectu non indignus (Cracow, 1572). Characteristically, in line with the principle observed at the time in the Reformed circles of the Polish-Lithuanian Commonwealth - of separating matters of faith from politics, this work is devoid of any explicit confessional references. ${ }^{61}$ Yet the subject matter

translations; Hermann Witsius, author of De oeconomia foederum Dei cum hominibus libri quatuor, Leeuwarden, 1677, numerous further editions and translations; Johannes Cocceius, Summa doctrinae de foedere et testamento Dei, Leiden, 1648, numerous further editions and translations. See Willem Jan Asselt, The Federal Theology of Johannes Cocceius (1603-1669), Leiden, 2001.

${ }^{57}$ Ronald J. VanderMolen, 'Providence as mystery, providence as revelation: Puritan and Anglican modifications of John Calvin's doctrine of providence', Church History, 47, 1978, 1, pp. 27-47; Antonie Vos, 'Reformed Orthodoxy in the Netherlands', in A Companion to Reformed Orthodoxy, ed. Herman Selderhuis, Leiden, 2013, pp. 119-96 (pp. 142-46).

${ }^{58}$ Krzysztof Obremski, ‘Sarmacki mesjanizm', Ogród: Kwartalnik, 7, 1994, 4, pp. 119-130.

${ }^{59}$ Andrzej Kempfi, 'Frycz a Wolan: Zapomniana karta recepcji Frycza w Polsce', in Andrzej Frycz Modrzewski a problemy kultury polskiego Odrodzenia, ed. Tadeusz Bieńkowski, Wrocław and Warsaw, 1974, pp. 203-18.

${ }^{60}$ Kęstutis Daugirdas, Andreas Volanus und die Reformation im Grossfürstentum Litauen, Mainz, 2008, pp. 281-86, Veröffentlichungen des Instituts für Europäische Geschichte Mainz, Abteilung für Abendländische Religionsgeschichte, vol. 221.

${ }^{61}$ Urszula Augustyniak, 'Granice wolności obywatela w XVI-XVII w. Jednostka wobec władzy, prawa i społeczeństwa', in Wolność i jej granice: Polskie dylematy, ed. Jacek Kloczkowski, Cracow, 2007, pp.13-37 (p.34). 
discussed in the book must have generated a lot of interest during Zebrzydowski's rebellion, as no fewer than two translations of the work into Polish were published at the time, the first at the beginning of the rebellion in 1606, and the second right after its end in $1611 .{ }^{62}$

The tendency to perceive reality in providentialist terms was strengthened by the fact that future Polish and Lithuanian pastors studied in Western faculties of theology, especially in the Netherlands and Germany. Thus Protestant providentialism existed in Poland alongside Catholic providentialism, although over time, especially from the mid-seventeenth century when the culture of the nobility came to be dominated by 'Sarmatian' (Baroque) Catholicism, it became increasingly clear that its focus was different from that of the Catholic interpretation and consequently so was the understanding of the functioning of providence and its impact on the fate of the Polish-Lithuanian Commonwealth.

Since it would be impossible to analyse here all early modern Protestant writings in the Polish-Lithuanian Commonwealth with regard to the intensity of providentialist views present in them, I will only present several examples of works which are of special interest to us from this point of view. As religious moralism and historiosophy are particularly promising forms in this respect, I have selected works from these two fields. Moralism is represented by two authors of postils, that is collections of sermons, popular in the late sixteenth and in the seventeenth century. Printed postils were a pastoral tool that was especially important to the Reformed diaspora communities and effectively shaped the views of the faithful.

The first author, Grzegorz of Żarnowiec, is one of the most outstanding Polish polemicists and Protestant theologians of the second half of the sixteenth century. He was born around 1528, most likely in Żarnowiec near Miechów. We know nothing about his education, but even his opponents considered him to be an eminent theologian. He worked as a preacher in Polish Reformed congregations; in the early 1580 s he became a minister in Włoszczowa, where he died in $1601 .^{63}$ The most important work in his oeuvre, in addition to his polemics against the Jesuits and the Polish Brethren, was Postylla albo wykłady ewanyeliey niedzielnych y na świętha przez cały rok...

${ }^{62}$ Andrzej Wolan, 0 wolności rzeczypospolitej albo ślacheckiej ksią̇ka godna ku czytaniu, transl. Stanisław Dubingowicz, Vilnius, 1606; Politica. O wolności polski pospolity, crypto-translation by Kasper Pepłowski, Poznań, 1611; see Roman Mazurkiewicz, 'Wstęp', in Andrzej Wolan, De libertate politica sive civili. O wolności Rzeczypospolitej albo ślacheckiej, transl. Stanisław Dubingowicz, ed. Maciej Eder and Roman Mazurkiewicz, sc. ed. Wacław Uruszczak, Warsaw, 2010, pp. 9-53.

${ }^{63}$ Halina Kowalska, 'Grzegorz z Żarnowca', in PSB, vol. 9, ed. Kazimierz Lepszy et al., Wrocław, Cracow and Warsaw, 1960-61, pp. 91-93. 
(Postils or Lectures on the Gospels for Sundays and Feast Days Throughout the Year...), printed by Maciej Wirzbięta for the first time in four volumes in Cracow in 1580-82. It was published four times, quickly translated into German (and apparently also into Czech and Lithuanian), and reissued as late as in the nineteenth century. ${ }^{64}$

The author was regarded as a moderate but firm advocate of orthodox Calvinism. In the discussions during the preparation of the Sandomierz Confession he spoke clearly against the theses of the Lutheran Augsburg Confession, and even apparently raised objections to the confession of the Unity of the Brethren, who were, after all, close to Calvinists. ${ }^{65}$ This is also the nature of his Postylla, the objective of which was not only to preach the truths of the Reformed faith, but also to fight against the views of heretics, primarily Catholics, and in particular the Jesuits, whom he described as a 'sect'. It was a work typical of the confessionalization period, apologist and controversial in nature, addressed to 'dear Christians', that is to readers (and listeners) with no extensive theological education. This is why the author focused on presenting the fundamental truths of faith, which he discussed in a variety of aspects. An additional element, facilitating the Postylla's reception, was provided by short summaries of the most important theses of the successive sermons or lectures. Structured in such a way in its second Polish edition, printed in Vilnius, Postylla became popular among Polish readers. ${ }^{66}$

Avoiding subtle philosophical distinctions and difficult theological terminology ${ }^{67}$ (which in any case had not yet emerged in the Polish language in most cases), Grzegorz of Żarnowiec focused on the dogmatic and liturgical differences between the Catholic and Reformed religions. When discussing God's attributes, he put the strongest emphasis on love and grace, which suggests that he was a firm, although moderate, providentialist. He devoted three full and extensive fragments of two other sermons to the question of providence. In the lecture for the fourth Sunday

${ }^{64}$ The second edition of Postylla was published in Königsberg in 1587 in Heinrich Kurtzbach's translation as Postilla, oder Außlegung der sontags Evangelien und anderer Fest der allgemeinen Kirchen durch das gantze Jahr; the third edition, revised by the author, was printed in Polish in Vilnius in 1597-1605 by Jan Karcan. The fourth edition, edited by Theodor Haase in Cieszyn, came out in 1864. For an analysis of its form and content, see Janusz T. Maciuszko, Ewangelicka postyllografia polska XVI-XVIII wieku: Charakterystyka - analiza porównawcza - recepcja, Warsaw, 1987, pp. 116-36. See also Magdalena Komorowska, 'Kształt edytorski postylli polskich XVI i XVII wieku - w poszukiwaniu staropolskich konwencji wydawniczych', Terminus, 17, 2015, 3(34), pp. 317-67.

${ }^{65}$ Renata Czyż, Obrona wiary w edycjach postylli Grzegorza z Żarnowca, Warsaw, 2008.

${ }^{66}$ Maciuszko, Ewangelicka postyllografia, p. 121.

${ }^{67}$ Ibid., p. 124. 
after Epiphany, entitled 'On the Church of God and strange dangers which come upon it in this stormy sea of the world and on the strange Divine Providence over it', he says that although divine providence leads the faithful to salvation, their faith is constantly put to the test. That is why it is essential to firmly believe in grace and the ultimate salvation of the faithful, so that they will not lose heart even when the Church and its servants are attacked. This may have been an allusion to the rise of the Counter-Reformation, which in the 1590s became increasingly political in nature. ${ }^{68}$

In the sermon for the Laetare Sunday, devoted to providence and entitled 'On the strange providence of our beloved God, who extends it to those sincerely seeking him and following him. And on how we should use the goods provided to us by the Lord God', the author repeats his earlier conviction that those who trust providence completely may rely on it. Both the grace of salvation and the protection of providence depend on a strong faith. The sermon also includes a lecture on Christian moderation in using material goods. ${ }^{69}$ The purpose may have been to emphasize the superiority of spiritual values.

The third lecture, for the fifteenth Sunday after the Feast of the Holy Trinity, has a long title which sums up the preacher's message: 'On the desertion of God and his sacred service by humankind to serve Mammon, and on the strange. Divine Providence he extends to the smallest of birds to see man with strong trust in him'.$^{70}$ In addition to repeated appeals to persevere in faith and trust in divine providence and grace, we have here a confirmation of Calvin's thesis that providence embraces not only people but the whole of creation.

Other remarks on the subject can be found in the remaining sermons. Of note is a phrase used in the sermon for the Feast of Epiphany: ' $O$, strange and unfathomable providence of the loving God, with which you view the needs of your faithful from afar... ${ }^{71}$ The terminology used here: whereby 'viewing the needs' of the faithful 'from afar' is a component of providence, resembles somewhat the phrases used by late medieval preachers, who had problems with conveying the deep sense of the Latin term providentia Dei in Polish. ${ }^{72}$ In the sermon for the first Sunday of Lent the preacher says that although God extends protective care to the faithful, it would be a sin to

${ }^{68}$ Grzegorz z Żarnowca, Postilla albo wykłady ewanieliy niedzielnych $i$ świąt uroczystych przez caty rok..., [Vilnius], 1597, second revised edition in Polish, fols 68 ver. -75 rec.

${ }^{69}$ Ibid., fols 125 ver. -131 rec.

${ }^{70}$ Ibid., fols 385 ver. -90 rec. See note 27.

${ }^{71}$ Ibid., fol. 48 rec.

${ }^{72}$ See note 26. 
put that divine providence to the test. Somewhat naively, though vividly, the preacher explains that God did not want people to fly, to go across waters without boats or to walk naked in freezing conditions, so they may not rely on providence when trying to break the natural order of creation. ${ }^{73}$

Grzegorz of Żarnowiec's teachings were addressed to the 'simple people of God' and as such they were without any special subtleties. The author wanted to convey and consolidate the most important principles of faith defined in the Sandomierz Confession. Reflection on providence is in the spirit of orthodox Calvinist ideas and draws on phrases rooted in the late medieval imagination. There are no clear references to covenant theology.

The second set of the postils analysed here, by Krzysztof Kraiński, son of Andrzej, lord of the village of Leszczowate near Sanok, are of a different nature. Born in 1556, he died on 21 January 1618 in Łaszczów, Belz Voivodeship. As in the case of Grzegorz of Żarnowiec, we have no information about the education of the future minister. From 1584 he was a preacher of the Lublin congregation, then minister in Opole Lubelskie and scholarch of the local Reformed gymnasium. A delegate to the 1595 general synod of the Reformed Church in Torun, in 1598 he was elected superintendent of the Unity of Lesser Poland, then served as co-senior of Lublin until 1603, minister in Łaszczów and from 1604 senior of the Districts of Belz, Volhynia and Kiev. Unlike Grzegorz of Żarnowiec, Kraiński was a nobleman and not a poor one at that - we know that he owned Hermanowice and Małkowice in the Przemyśl Land. ${ }^{74}$

In the late sixteenth century Kraiński was working hard to strengthen and consolidate the confessional identity of the Polish Reformed Protestants, a process facilitated by the loosening of ties with the Lutherans dating back to the Synod of Torun. ${ }^{75} \mathrm{He}$ began with efforts to reorganize the Unity of Lesser Poland and then to strengthen the foundations of the faithful's religious awareness. He published three editions of the catechism as well as a collection of prayers (Dziennik to iest modlitwy, Vilnius, 1605); sought to unify the liturgy (Porzadek nabożeństwa Kościoła powszechnego apostolskiego, Toruń, 1599 and Kancyonał, abo pieśni duchowne, no place

${ }^{73}$ Grzegorz z Żarnowca, Postilla, fol. 110 rec.

${ }^{74}$ Janusz Tazbir, 'Kraiński Krzysztof', in PSB, vol. 15, ed. Bogusław Leśnodorski et al. Wrocław, Warsaw and Cracow, 1970, pp. 92-93.

${ }^{75}$ Kazimierz Szkadłubowicz, ‘Kilka szczegółów z życia Krzysztofa Kraińskiego’, in Studia z dziejów kultury polskiej: Książka zbiorowa, ed. Henryk Barycz and Jan Hulewicz, Warsaw, 1948, pp. 333-48; Stanisław Tworek, 'Starania o ujednolicenie obrządku kalwińskiego w Polsce XVII w.', OiRP, 16, 1971, pp. 117-39. 
given 1609); and crowned his achievements with three volumes of Postylla $(1608,1611,1617)$, a valuable source for the study of the mentality of Polish Reformed Protestants in the early seventeenth century. ${ }^{76}$

Kraiński was part of a generation of Reformed ministers who were prone to theological orthodoxy, so characteristic of the confessionalization era - hence perhaps the frequent references to the Old Testament in his writings. ${ }^{77}$ Another characteristic of his writings is an aversion to Antitrinitarians, whom he blamed not only for their 'heretical' theological doctrines, but also for their political weakening of the Polish Reformation following the split in the 1560s. However, what matters most from our point of view is the observation that the basis for Krainski's theological ethics was a strong belief in providence. ${ }^{78}$

Unlike Grzegorz of Żarnowiec, who in his homilies shied away from evident references to the political reality, Kraiński liked to take a stance on the problems of the Reformed Church in the Polish-Lithuanian Commonwealth. Let us begin with his attitude toward the state. Kraiński's views were line with the political theology, the foundations of which were laid in Chapter 20, Book IV, of Institutio christianae religionis from 1559 by Calvin: the government, which always rules by the will of providence, should be obeyed; it determines the religion of the state and has the duty to supervise divine worship. However, obedience applies only in matters 'which are not against God, faith, and honest conscience'. People must refuse to follow laws and orders which are against their conscience and must bear the consequences of this, trusting providence. Only legal representatives of the faithful were authorized to protest officially. These views were known in the Polish-Lithuanian Commonwealth not only to Reformed theologians, but also to secular readers, as the chapter devoted to them in Calvin's opus magnus was the first fragment published in Polish. ${ }^{79}$

Conversely, the civil government, which should be obeyed, had a duty to care for the earthly well-being and salvation of their subjects. For Kraiński and his readers in the first decades of the seventeenth century it must have been obvious that the king in the Polish-Lithuanian Commonwealth

${ }^{76}$ Janusz Tazbir, “"Kopalnia najciekawszych szczegółów...” (Postylla Krzysztofa Kraińskiego)’, OiRP, 28, 1983, pp. 195-231. Maciuszko, Ewangelicka postyllografia, pp. 163-86.

${ }^{77}$ Joanna Jelińska, 'Sarmacki' wizerunek szlachcica-ewangelika w Postylli Krzysztofa Kraińskiego, Warsaw, p. 10.

${ }^{78}$ Maciuszko, Ewangelicka postyllografia, p. 179.

${ }^{79}$ Jan Kalwin, O zwierzchności świeckiej, porzadne, według sznuru Pisma świętego opisanie. Zaraz o pożytkach i powinnościach urzędu jej. Z łacińskiego na polskie wiernie przetłumaczone: Anonimowy przekład polski dwudziestego rozdziału czwartej ksiegi 'Institutio Christianae religionis nunc uere demum suo titulo respondens' Jana Kalwina wydany w 1599 r., introduction and ed. Wojciech Kriegseisen, Warsaw, 2009. 
did not meet the Protestants' expectations concerning the supervision of religious worship; moreover, it authorized the 'blasphemous' worship of the Jews, Muslims and 'idolaters' [Orthodox Christians, Catholics - W.K.] and increasingly sought to curtail the Reformed Protestants' freedoms. ${ }^{80}$

It seems, however, that Kraiński's views on the relationship between the Catholic central government and the confessionally diverse society of the Polish-Lithuanian Commonwealth are inconsistent. He was an apologist of the confessional peace symbolized by the Warsaw Confederation, but did not approve of equal rights for all denominations - he excluded the Polish Brethren from the 'company, partnership and concord'. ${ }^{81}$ When it came to relations with heretics, he argued for tolerance, but it did not apply to the 'most harmful superstition'. However, referring to the biblical parable of the darnel, he denied governments (including non-Catholic governments) the right to punish heretics and pointed out that confessional conflicts weakened the state. Agreeing with Justus Lipsius, he justified toleration for 'peaceful' dissenters in a similar fashion, however Kraiński reiterated that such toleration meant choosing the lesser evil: 'verily, it is an infernal matter [...] to allow anyone to believe as he pleases, the worst thing being letting anyone perish, if he wishes. ${ }^{.82}$

An explanation of this apparent inconsistency must lie in providentialism, that is a belief in providence understood as the implementation of God's plan of salvation, thanks to which - despite all the imperfections of the temporal world - the faithful and the just will triumph at the end of times. It should also be stressed that Krainski addressed these political-theological reflections to an audience different from that of Grzegorz of Żarnowiec. It encompassed not only all the Protestant faithful, but also (perhaps even above all) the Reformed Protestants among the nobility, who still felt they were equal citizens of the Polish-Lithuanian Commonwealth at the time, despite a growing sense of threat to religious freedoms.

Thus in his views on the state Kraiński represented Reformed orthodoxy and at the same time was a regalist. In one case only did he mention a possibility of refusing obedience to the king - if the king refused to respect the Warsaw Confederation. ${ }^{83}$ This can be linked to the demands of the Sandomierz Rebellion - the first two volumes of Postylla appeared in print shortly after the rebellion had ended, and the matter of the practical (statutory) implementation of the decisions, that is the 'process', of

${ }^{80}$ Krzysztof Kraiński, Postylla, part 1 and 2, Łaszczów, 1611, fols 84 rec.-85 rec., 475 rec.-83 rec.; part 5, Raków, 1617, pp. 1274-75.

${ }^{81}$ Ibid., part 5, p. 1290.

${ }^{82}$ Ibid., part 2, fols 499 rec. -500 rec.

${ }^{83}$ Tazbir, “"Kopalnia najciekawszych szczegółów...”, pp. 214-16. 
the Warsaw Confederation, which in 1606 became the direct cause of the outbreak of the rebellion, was still a current topic in political discussions.

As a Reformed theologian, Kraiński regarded the political conflicts and elementary disasters plaguing the state in the early seventeenth century as the work of providence. In his opinion they were punishments for 'obscene idolatry', multiple 'apostasies' on the part of Reformed Protestants, as well as an encouragement for Poles to 'convert' to the Reformed religion. ${ }^{84} \mathrm{He}$ had a feeling of a deepening crisis in the Reformed congregation in the Polish-Lithuanian Commonwealth and recommended the victims of persecutions to embrace providence, encouraging trust in the ultimate triumph of justice. ${ }^{85}$ Although he did not formulate this explicitly, he undoubtedly dreamed of the Polish-Lithuanian Commonwealth as a Reformed state, which should introduce limited toleration, excluding 'obscene' extremes, such as Antitrinitarians and 'idolaters' (most likely Catholics). Yet he left it to providence to take care of the matter.

It also seems that Kraiński's views were representative of politically active members of the Reformed Church in the Polish-Lithuanian Commonwealth. In an anonymous piece from the turn of the seventeenth century, attributed to Piotr Kochlewski, we find complaints about the fact that many Polish and Lithuanian Protestants had lost hope for an improvement in confessional relations: 'When judging things past by external appearances and leaving almost no room to the power of divine providence, they lost heart, they doubted if they would ever be able to save things in decline.' The author points out that the evil affecting the Protestants in the Polish-Lithuanian Commonwealth is a punishment for their sins, but they should not doubt in the ultimate success, for the fate of the world is in the hands of providence, which determines everything. ${ }^{86}$

Let us now move to historical works. Interestingly, probably the best known work of Polish Protestant historiography in the seventeenth century, a book by Andrzej Węgierski (appearing under the pseudonym Adrianus Regenvolscius) - published in Utrecht in 1652 as Systema historico-chronologicum ecclesiarum Slavonicarum per provincias varias ${ }^{87}$ - contains no providentialist themes. It would seem to have been impossible for the author, born in 1600 in a family of Czech Brethren, whose five sons became

${ }^{84}$ Kraiński, Postylla, part 1 and 2, fols 52 rec., 388 ver.

${ }^{85}$ Ibid., part 1, fol. 53 rec.

86 'Pobożnego ewangelika do braciej tegoż wyznania narodu polskiego i litewskiego przestroga i upomnienie, ręką pana Kochlewskiego pisana', in Państwo świeckie czy księże?: Spór o rolę duchowieństwa katolickiego w Rzeczypospolitej w czasach Zygmunta III Wazy: Wybór tekstów, ed. Urszula Augustyniak, Warsaw, 2013, pp. 179-233 (pp. 180, 200, 206-07).

${ }^{87}$ Utrecht 1652. The work had a second edition, to which Andrzej Wiszowaty added 
clergymen, to challenge the doctrine of providence, at least in the form presented in Article 6 of the Sandomierz Confession. He must have come across this doctrine in the Reformed schools in Ostroróg and Leszno, in the gymnasiums of Bytom Odrzański (Schönaichianum) and Toruń, as well as at Leiden University. As a graduate of these schools Węgierski was ordained deacon in 1622, from 1629 was a minister and rector of the school in Leszno, where he collaborated with Jan Ámos Komenský, and from 1633 was a minister at the Włodawa congregation and eleven years later was elected senior of the Lublin District of the Unity of Lesser Poland. Thus his orthodoxy was beyond doubt. He died in 1649 in Greater Poland, where he had taken refuge during the Khmelnytsky Uprising. ${ }^{88}$

His acceptance of providentialism is also evidenced by his writings, especially his occasional writings. ${ }^{89}$ The lack of such references in a historiographical work published after the author's death, with an introduction by the eminent Dutch Reformed theologian Gisbertus Voetius, professor at Utrecht University, is explained by the nature of the book. Systema historico-chronologicum is - as its very title suggests - a kind of compendium of information and not a historiosophical treatise. This is probably the reason why there is no moralizing, so characteristic of 'pre-academic' historiography, especially historiography written from the confessional perspective.

As has already been mentioned, providentialists included the Polish Brethren, as is best seen in the case of the historiosopher Andrzej Lubieniecki the elder. He was born around 1551 to a Calvinist couple, Stanisław and Katarzyna, née Sobieska. From 1560 he may have been a pupil at the Reformed gymnasium in Bychawa, and then served at the court of Sigismund Augustus, leaving for Paris after the king's death. He returned to Poland with Henry de Valois and after his escape became Stephen Báthory's courtier. Around 1582 he abandoned his career at the court, accepted the religion of the Polish Brethren and

the history of the Polish Brethren, published under the name of Andrea Wengerscii and the title Libri quattuor Slavoniae reformatae, Amsterdam, 1679. Modern edition: Libri quattuor Slavoniae reformatae, pref. Janusz Tazbir, Warsaw, 1973, Biblioteka Pisarzy Reformacyjnych, vol. 11.

${ }^{88}$ Janusz Tazbir, 'Andrzej Węgierski - historyk słowiańskiej reformacji', in Ars Historica: Prace z historii dziejów powszechnych i Polski, ed. Marian Biskup et al., Poznań, 1976, pp. 603-16.

${ }^{89}$ Wacław Urban, 'Epitalamia i epitafia pastorskiej rodziny Węgierskich w XVII w.', in Wesela, chrzciny i pogrzeby w XVI-XVIII wieku: Kultura życia i śmierci, ed. Henryk Suchojad, Warsaw, 2001, pp. 167-72; idem, 'Rola braci Węgierskich w podtrzymywaniu protestantyzmu polskiego', in Religia, edukacja, kultura: Księga pamiattkowa dedykowana Profesorowi Stanisławowi Litakowi, ed. Marian Surdacki, Lublin, 2002, pp. 47-51. 
became their minister, first in their congregation in Śmigiel and then in Hoszcza. In the early seventeenth century he lived in Raków, where he was the Academy's scholarch. He died in 1623 in Siedliska, District of Krasnystaw..$^{90}$

Initially Lubieniecki apparently succumbed to chiliasm, as was evidenced by the lost treatise De regno Christi millenario. ${ }^{91}$ However, his most important work was Polonoeutychia abo Polskiego Królestwa szczęście (Polonoeutychia or the Happiness of the Polish Kingdom (the Latin-Greek hybrid poloneutychia can also be translated as 'Polish providence' ${ }^{92}$ ). The treatise is divided into two parts. The first is devoted to the history of the Kingdom of Poland as a happy state, with special attention being paid to the Jagiellonian period. Part two deals with the crisis in the Polish-Lithuanian Commonwealth following the collapse of confessional equality. In this respect the year 1611 was of particular importance, which the author believed to have been the end of the period of the state's prosperity, that is providence's 'prize' for observing the provisions of the Warsaw Confederation. He stated that: 'on this occasion God added much to our freedoms and liberties, and thus peace in our fatherland and in our consciences, whence the great celebration and our prosperity. ${ }^{93}$

Lubieniecki, a historian and moralist from the Polish Brethren milieu, idealized Catholic rulers, especially Sigismund Augustus: 'For he was a happy king, he refused to interfere with the Lord Jesus's work, leaving to him what was due to his authority and to his angels. ${ }^{94}$ Lubieniecki was less positive about Henry de Valois and Stephen Báthory, although he did not reproach the latter for the 1580 edict which banned the printing of historical works without the court's approval and thus introduced censorship..$^{95}$ However, Lubieniecki was at his most eloquent when praising the first period of Sigismund III's reign, because the king recognized the Warsaw Confederation and 'promised [...] trial or execution for the violatores of this confederation. Did we not live in peace in Poland and Lithuania thanks to these pledges, although here and there were the

90 Janusz Tazbir, 'Lubieniecki Andrzej starszy', in PSB, vol. 17, Wrocław, 1972, pp. 594-96; Henryk Barycz, 'Optymistyczna wizja dziejów narodowych', in idem, Szlakami dziejopisarstwa staropolskiego: Studia nad historiografia w. XVI-XVIII, Wrocław, 1981, pp. 203-42.

${ }^{91}$ Janusz Tazbir, 'Wstęp', in Andrzej Lubieniecki, Polonoeutychia, ed. Alina Linda et al., Warsaw and Łódź, 1982, p. IX, note 19.

${ }_{92}$ Bömelburg, Polska myśl historyczna, p. 504.

${ }^{93}$ Lubieniecki, Polonoeutychia, pp. 64, 105.

${ }^{94}$ Ibid., p. 55, similarly pp. 142-43.

${ }_{95}$ Bömelburg, Polska myśl historyczna, pp. 257-61. 
walls of our churches violated by rogues. ${ }^{96}$ Such an assessment may have been prompted by the author's attachment to a political system that still guaranteed a high level of political and religious freedom for the nobility. This is how Janusz Tazbir wanted to convey this in his Introduction to the edition of Polonoeutychia quoted here. ${ }^{97}$

This might also explain Lubieniecki's opinion about the Habsburgs: 'And these Austrian princes are closer to us, as they do not fight against the Lord Jesus ex diametro, are also beloved by him, and are blessed with beautiful virtues, honours and fame. ${ }^{98}$ This applies to three tolerant emperors: Ferdinand I, Maximilian II and Matthias, and - surprisingly - Archduke Ernest Habsburg, who rendered great service to the Counter-Reformation and was an ill-considered candidate for the Polish throne in 1587. But Lubieniecki devoted the most attention to Emperor Charles V, using him as an example to demonstrate the working of providence. The failed attempt to capture Algiers in 1541, as well as defeats in the war against Turkey, were presented as punishments for the pledge of allegiance made to Pope Clement VII during the imperial coronation in Bologna in 1530. ${ }^{99}$

Unlike Andrzej Węgierski's oeuvre, Lubieniecki's book is not the work of a chronicler. It is a historiosophical treatise and the reflections of the author - a nobleman and a Protestant - are presented from a confessional point of view. It is dominated by 'Sarmatian' providentialism, or even Messianism. Poles have been chosen by God and given political and religious freedom, which they will keep, provided they respect 'God-fearing people', that is true believers in the Gospel. Violations of religious freedom will lead to a collapse of political freedom as well as the collapse of the state, for providence follows the Old Testament principle of collective responsibility. ${ }^{100}$

This strand of Protestant religious historiography was continued by Stanisław Lubieniecki the younger, Andrzej's nephew. Born in 1623 in Raków, to Krzysztof, the local minister of the Polish Brethren, he was first educated in Raków, and after the closure of its Academy - in the Polish Brethren's gymnasium in Kisilin, Volhynia. He went on to study at foreign universities: Catholic in Orleans and Angers, Reformed the academy

${ }^{96}$ Lubieniecki, Polonoeutychia, p. 91.

${ }^{97}$ Ibid., pp. X-XI.

${ }^{98}$ Ibid., p. 130.

${ }^{99}$ Ibid., pp. 130-34.

100 Tazbir, ‘Wstęp', pp. XI-XIII. See also Antoni Krawczyk, 'Historiozoficzna wizja procesu dziejowego w Poloneutychii Andrzeja Lubienieckiego', Res Historica, 10: Z dziejów stosunków wyznaniowych w Rzeczypospolitej XVI-XVII wieku: Materiały konferencji naukowej 'Jan Niemojewski - polska reformacja - przełom stuleci', Lublin 26-27 listopada 1998 roku, ed. Henryk Gmiterek, 2000, pp. 119-39. 
in Saumur, and finally in Leiden. After returning to Poland he worked as a minister for the Polish Brethren in their congregations in Siedliska and Czarkowy. After the outbreak of the war in 1655 he became a delegate of his fellow believers and was sent to obtain a guarantee of toleration from the Swedish authorities. As the Swedes withdrew from Poland, he found himself with them in Western Pomerania and remained abroad - mainly in Hamburg and Altona, where he died in $1675 .{ }^{101}$

Lubieniecki's best known work, apart from his religious and political writings and his treatise on comets (a result of his dabbling in astronomy) ${ }^{102}$ was Historia reformationis Polonicae, published posthumously in Amsterdam. ${ }^{103}$ Continuing the ideas of orthodox Protestant historiography, ideas formulated already in the sixteenth century, with the concept of testis veritatis, the author concluded that God was the lord of history, and therefore, history stemmed from the will and plan of providence, the general intention of which was the salvation of the faithful. ${ }^{104}$ The belief in the direct influence of providence on the history of the Polish-Lithuanian Commonwealth and on the disasters affecting it (as punishments for violating religious freedoms) was a providentialist thread common to Stanisław and his uncle Andrzej Lubieniecki.

Already in the title of the first book of Historia reformationis we find a clear declaration: Liber I. Quo demonstratur, qui Deus pro immensa sua sapientia et bonitate ab initio veritatis Apostolicae cum hominibus sequentibus seculis egerit, quique per certas gradus reformationem Ecclesiae in Polonia inchoavit. ${ }^{105}$

${ }^{101}$ Janusz Tazbir, ‘Lubieniecki Stanisław młodszy’, in PSB, vol. 17, pp. 603-07.

${ }^{102}$ For more on Lubieniecki's overestimated astronomical competences, see Maciej Jasiński, Stanisław Lubieniecki i astronomia kometarna XVII stulecia, Warsaw, 2017.

${ }^{103}$ Historia reformationis Polonicae in qua tum reformatorum, tum antitrinitariorum origo et progressus in Polonia et finitimis provinciis narrantur authore Stanislao Lubieniecio, Amsterdam, 1685; modern edition: Stanislai Lubieniecii Historia reformationis Polonicae, pref. Henryk Barycz, Warsaw, 1971, Biblioteka Pisarzy Reformacyjnych, vol. 9; Polish translation (incomplete): Stanisław Lubieniecki, Historia reformacji polskiej, w której przedstawia się początki oraz rozwój zarówno zreformowanych jako też antytrynitarzy w Polsce oraz w ziemiach sasiednich, transl. and ed. Edmund Bursche, Book 1, Rocznik Teologiczny, 3, 1938, pp. 181-281, Book 2, Rocznik Teologiczny, 4, 1939, pp. 1-190.

${ }^{104}$ Henryk Barycz, 'Stanisław Lubieniecki - historyk reformacji polskiej', in idem, Szlakami dziejopisarstwa staropolskiego, pp. 243-66 (p. 259); Antoni Krawczyk, Historiografia krytyczna: Formowanie się nowożytnej postawy naukowej w polskim piśmiennictwie historycznym XVII wieku, Lublin, 1994, p. 31 f.; Janusz Tazbir, Stando lubentius moriar: Biografia Stanisława Lubienieckiego, Warsaw, 2003, pp. 186-92,197.

105 Stanislai Lubieniecii Historia reformationis, p. 1; translation: 'Book One, in which it turns out how God from the very beginning of the apostolic truth over the following centuries dealt with people in accordance with his immense wisdom and goodness, and how he gradually began the Reformation of the Church in Poland.' Lubieniecki, Historia reformacji polskiej, Book 1, p. 213. 
In line with this assumption, when Lubieniecki talks about Sigismund Augustus, he attributes the successes of his reign to providence: 'Principum laudatissimo Deus Opt. Max. hanc felicitatis praerogativam tribuit, ut sub eo, utpote et rerum pace belloque gestarum gloriam et virtutum elogiis Clarissimo...' ${ }^{106}$

The beginnings of the Reformation in the Kingdom of Poland were also a decision of providence, which entrusted this work to Sigismund Augustus's monarchic power: 'Hujus itaque Gloriosissimi et Optimi Regum temporibus, Deus reformationis initium in regno fieri voluit, ut nemini salva tanti Regis reverentiam tantum opus impedire liceret. ${ }^{107}$ And although an inquiring reader might ask why it proved impossible to complete this work, there is no doubt that the author's view is providentialist, or even close to covenant theology.

Sometimes, as in the anecdote about Bishop Samuel Maciejowski's unsuccessful search for the works of Luther and Calvin in Francesco Lismanino's monastery cell in Cracow, or about the accusation of heresy made against him by the authorities of Venice after he had left the city, Lubieniecki's belief in providence's direct influence on the fate of individuals was expressed in descriptions which are rather similar to stories popular in Catholic devotional literature - of 'miraculous' interventions on the part of providence or of its tool, the guardian angel. ${ }^{108}$

However, there is no doubt that the Lubienieckis and the Polish Brethren, like the Calvinists referred to earlier, believed in providence's direct influence on the fate of the Polish-Lithuanian Commonwealth, and that this belief was based on theological foundations common to all Christians. Thus the growing providentialist tendencies in Polish culture of the seventeenth century cannot be regarded as unique to Catholic Sarmatism. However, the understanding of the operation of providence evolved differently in Protestantism and in Catholicism. Protestant theologians stressed the concept of the divine plan of salvation, understood as the Creator's pre-eternal and all-encompassing intention. Thus for the Reformed providentialists phenomena viewed as individual interventions of providence (for example, miracles) were less important, and the crucial role was played by the place of individuals as well as human groups and entire nations in God's plan of salvation.

${ }^{106}$ Ibid., p. 14; translation: 'God Almighty himself showed King Sigismund II, Augustus by name and in fact, held in the highest regard among all princes, some excess of felicity...', ibid., p. 241.

${ }^{107}$ Ibid., p. 16; translation: 'During the reign of this most glorious and best king, God deigned to begin reformation in his kingdom so that nobody would dare impede this work in the face of such a king.' Ibid., p. 245.

${ }^{108}$ Ibid., pp. 23-24. 
In the seventeenth century, and especially in its second half - marked by a transformation of the Catholic confessional identity and the Sarmatization of its expression in culture and art, a process accelerated by political events - this meant in practice not only acceptance of the Baroque, 'rich' form in liturgy and art, but also exclusion of 'the others', that is non-Catholics above all, from the body politic. ${ }^{109}$ Consequently, the hitherto insignificant differences between Catholics and Protestants in the interpretation of the operation of providence grew increasingly important. For the Catholics, divine providence and the intercession of the Queen of the Polish Crown saved the Polish-Lithuanian Commonwealth from the 'deluge' and protected it against other threats until well into the eighteenth century; while for the Protestants providence carried out its plan of salvation by putting the orthodox to the test of faith and at the same time punished the Catholic state for persecuting them.

What for the Catholics was viewed as a success resulting from great zeal in religious practices, was seen by the Protestants as a difficult challenge and a failure of the ideas symbolized by the Warsaw Confederation. While in the early seventeenth century the Catholic and Reformed interpretations of the doctrine of providence seemed to differ only in their focus - which enabled both to participate in the culture of the 'Renaissance Sarmatism' - towards the end of that century the 'Baroque Sarmatism' became largely Catholic in nature. The nobility of the Reformed denomination could only invoke old laws, appeal for tolerance and keep pointing out that they were still part of the 'nation of nobles'. ${ }^{110}$

In conclusion it has to be said that from the point of view of research into the confessional relations in the early modern Polish-Lithuanian Commonwealth it would be hard to recognize the existence of a 'Sarmatian' identity common to the entire period from the mid-sixteenth to the mid-seventeenth century. Referring to Jakub Niedźwiedź's reflections cited

${ }^{109}$ For more on the evolution of the identity of lay Catholics in the seventeenth century and the manifestation of this process in art, see Małgorzata Hanusiewicz-Lavallee, 'Dawne i nowe: Tożsamość wyznaniowa katolików świeckich w potrydenckiej Rzeczypospolitej', in Formowanie kultury katolickiej w dobie potrydenckiej: Powszechność i narodowość katolicyzmu polskiego, ed. Joanna Dąbkowska-Kujko, Warsaw, 2016, pp. 103-44.

110 See for example arguments in [Daniel Ernest Jabłoński], Jura et libertates dissidentium in religione christiana in Regno Poloniae et M.D. Lithuaniae..., [Berlin], 1708, [1st edn]; Wojciech Kriegseisen, Ewangelicy polscy i litewscy w epoce saskiej (1696-1763): Sytuacja prawna, organizacja i stosunki międzywyznaniowe, Warsaw, 1996, pp. 169-226; Marta Bečková, 'Daniel Ernst Jablonski und seine Beziehungen zu Polen', in Daniel Ernst Jablonski: Religion, Wissenschaft und Politik um 1700, ed. Joachim Bahlcke and Werner Korthaase, Wiesbaden, 2008, pp. 206-22, Jabloniana: Quellen und Forschungen zur europäischen Kulturgeschichte der Frühen Neuzeit, vol.1. 
at the beginning of this work, we need to point out that the twentieth-century, and probably also the contemporary perspective, of looking at the culture of Sarmatism was imposed by the Romantic and post-Romantic literature, which cultivated a Sarmatian vision of the Commonwealth of the nobility with fondness, although not without irony, as in the case of Juliusz Słowacki. The generational and historical memory of nineteenth-century writers who contributed the most in this respect - such as Adam Mickiewicz, the author of Pan Tadeusz as well as, perhaps above all, minor writers like Henryk Rzewuski, author of $\mathrm{Pa}$ miatki Soplicy, or Wincenty Pol, author of Mohort, a 'chivalric rhapsody' - concentrated on the period closest to them, that is the eighteenth century, an era of 'Catholic Sarmatism'. ${ }^{111}$

It does not seem however that it would be useful for future research into Sarmatism to maintain this traditional perspective, especially in studies of confessional relations, religious culture, piety, as well as historiosophical concepts and views on the history of the Polish-Lithuanian Commonwealth. From this point of view there were at least two Sarmatisms in the history of Polish culture. First there was 'Renaissance Sarmatism', which evolved in the sixteenth century, and then came 'Baroque Sarmatism', developed in the seventeenth century. From the political and confessional point of view, the most important feature of 'Renaissance Sarmatism' was its unification in a common myth and ideology of the multi-ethnic, multicultural and multireligious nobility of the Polish-Lithuanian Commonwealth, the best known effect of which was the 1573 Warsaw Confederation.

On the other hand the culture of 'Baroque Sarmatism' - a product of the Counter-Reformation and efforts to bring about the Catholic confessionalization of the Commonwealth's society - had strong and over time increasingly effective elements which excluded cultural and religious diversity in a still multiethnic and multireligious society. This led directly to xenophobia and laid the foundation for an idea which came to be symbolized slightly later by the notion of Polak-katolik, implying a bond between Polishness and Catholicism. In the eighteenth-century the cultivation of the idea of 'Baroque Sarmatism', as well as attempts at its political implementation by the Bar Confederates, would prove to be among the causes of the first partition of the Polish-Lithuanian Commonwealth. This provided a pretext for the 'neighbouring powers'

111 Aleksander Łucki, 'Wstęp', in Wincenty Pol, Mohort, introduction and ed. Aleksander Łucki, Cracow, 1925, pp. III-XXXIV (pp. III-VIII), Biblioteka Narodowa, ser. 1, vol. 52 . 
who were interested in partitioning Poland, and also constituted a convenient pretext for passivity on the part of the elites of other European states already upholding the ideas of the Enlightenment.

In the final analiysis it is worth paying attention to a certain political consequence of Protestant providentialism. In the light of what we know today about confessional relations in the Polish-Lithuanian Commonwealth during the reign of Sigismund III, the positive and sometimes even apologist assertions by prominent Polish Protestant clergymen and writers concerning Catholic rulers, especially from the House of Habsburg, may seem incomprehensible. This might be explained by the fact that they adopted the opinion of those noblemen who were attached to the vision of a free Polish-Lithuanian Commonwealth but who were essentially regalists. This line of reasoning was followed by Janusz Tazbir.

Yet there is a slightly different possible explanation for the contradiction that seems to emerge today in connection with the regalism of non-Catholic clergymen and writers in the seventeenth century. We must not forget that the authors cited here represented - either explicitly (in the case of Kraiński) or implicitly (in the case of Lubieniecki) - the views of Protestant political theology with all its reflections on Christian freedom, predestination, God's plan of salvation as well as the covenant between God and people, the significance of which is stressed so strongly in recent studies by C. Scott Dixon and John Coffey. ${ }^{112}$ From this came the call to respect the government established by the will of providence, at least a government that was not tyrannical. Obedience to authority, even heretical and hostile authority, was proof of trust in providence and belief in the ultimate triumph of justice; and strong faith was, after all, the only guarantee of salvation. The conviction that 'everything is in God's hands' can also explain why the Protestants - who were so significant politically in the Polish-Lithuanian Commonwealth at the turn of the seventeenth century - did not, in contrast to their Bohemian fellow believers, choose to put up armed resistance to the state-supported Counter-Reformation and subsequent Catholic confessionalization.

(Translated by Anna Kijak)

(Proofreading James Hartzell)

112 C. Scott Dixon, Protestants: A History from Wittenberg to Pennsylvania 1517-1740, Chichester, 2010, p. 54; John Coffey, 'The Language of Liberty in Calvinist Political Thought', in Freedom and the Construction of Europe, ed. Quentin Skinner and Martin van Gelderen, 2 vols, Cambridge, 2013, vol. 1: Religious freedom and civil liberty, pp. 296-316. 


\section{Summary}

The aim of this study is to draw attention to those aspects of religious culture in the Polish-Lithuanian Commonwealth which are essential to research into Sarmatism. Sarmatism, as the dominant cultural formation in the mentality of the nobility from the sixteenth to the eighteenth centuries, continues to be described from the perspective imposed in the nineteenth century by writers cultivating the old tradition of the nobility, rooted primarily in the eighteenth-century reality. In practice this means that the culture of Sarmatism is perceived today primarily in its decadent form. What is regarded as one of the characteristic features of Sarmatism is a belief in the special care of divine providence as well as in the Virgin Mary Queen of the Polish Crown extended to the Commonwealth of the nobles. Yet in the sixteenth and seventeenth centuries providentialism was also characteristic of the Polish and Lithuanian Protestants. Both the Catholics and the Protestants drew on a shared doctrinal foundation laid down in late Antiquity. In the sixteenth century Sarmatism as an ideology and form of the culture of the nobility was accepted in a supra-religious sense and played a unifying role for the multiethnic and multireligious 'noble nation' of the Polish-Lithuanian Commonwealth. In the seventeenth and eighteenth centuries Sarmatism as a cultural formation came to be dominated by the ideology of first the Counter-Reformation, and then Catholic confessionalization, which led to the exclusion of non-Catholics and was conducive to xenophobia as well as the cultural Quietism, as it were, of the nobility. Consequently, it seems useful to introduce a distinction between the earlier, unifying 'Renaissance Sarmatism' and the later, excluding 'Baroque Sarmatism'.

(Translated by Anna Kijak)

(Proofreading James Hartzell)

\section{Bibliography}

\section{Sources}

[Augustine of Hippo] Św. Augustyn, Dar wytrwania, do Prospera i Hilarego, transl. Wacław Eborowicz, in Łaska, wiara, przeznaczenie, ed. Wacław Eborowicz, Poznań: Księgarnia św. Wojciecha, 1971, pp.335-85.

[Augustine of Hippo] S. Aurelii Augustini, De diversis quaestionibus octoginta tribus, in idem, Opera omnia, PL, vol. 40, 〈http://www.augustinus.it > [accessed 17 March 2021].

[Augustine of Hippo] S. Aurelii Augustini, De dono perseverantiae liber unus. Liber ad Prosperum et Hilarium secundus, in idem, Opera omnia, PL, vol. 45, <http:// www.augustinus.it $>$ [accessed 17 March 2021].

[Augustine of Hippo] S. Aurelii Augustini, De Trinitate libri quindecim, in idem, Opera omnia, PL, vol. 42, 〈http://www.augustinus.it> [accessed 17 March 2021]. 
[Augustine of Hippo] Św. Augustyn, Księga osiemdziesięciu trzech kwestii, trans. Ida Radziejowska, Kęty: Marek Derewiecki, 2012.

[Augustine of Hippo] Św. Augustyn, O Trójcy Świętej, transl. Maria Stokowska, Cracow: Wydawnictwo Znak, 1996.

Burman, Frans, Synopsis theologiae et speciatim foederum Dei ab initiis saeculorum usque ad consummationem eum, Utrecht: [n. pub.], 1671.

Cocceius, Johannes, Summa doctrinae de foedere et testamento Dei, Leiden: [n. pub.], 1648.

Formuła zgody z 1577 roku, transl. Józef Pośpiech, Bielsko-Biała: Augustana, 2003.

Gomarus, Franciscus, Conciliatio doctrinae orthodoxae de providentia Dei, Leiden: Officina Plantiniana, 1597.

Grzegorz z Żarnowca, Postilla albo wykłady ewanieliy niedzielnych $i$ świąt uroczystych przez cały rok..., [Vilnius]: [n. pub.], 1597.

Grzegorz z Żarnowca, Postylla albo wykłady ewanyeliey niedzielnych y na świętha przez cały rok..., [Cracow]: [n. pub.], 1580-82].

[Jabłoński, Daniel Ernest], Jura et libertates dissidentium in religione christiana in Regno Poloniae et M.D. Lithuaniae..., [Berlin]: [n. pub.], 1708.

[Calvin John], Brevis responsio Io. Calvini ad diluendas nebulonis cuiusdam calumnias quibus doctrinam de aeterna Dei praedestinatione foedare conatus est (1557), in Joannis Calvini opera quae supersunt omnia, 59 vols, ed. Eduard Cunitz, Johann-Wilhelm Baum and Eduard Wilhelm Eugen Reuss, Braunschweig: C.A. Schwetschke, 1863-1900, vol. 9, 1870, pp. 253-66.

[Calvin John], Calumniae nebulonis cuiusdam, quibus odio et invidia gravare conatus est doctrinam Ioh. Calvini de occulta Dei providentia (1558), in Joannis Calvini opera quae supersunt omnia, vol. 9, pp. 269-318.

[Calvin John], Ioannis Calvini Institutio christianae religionis, ed. August Tholuck, pars 1, Berlin: G. Thome, 1846.

Kalwin, Jan, Istota religii chrześcijańskiej. Institutio christianae religionis, księga pierwsza, transl. Janusz Kucharczyk et al., Świętochłowice: Towarzystwo Upowszechniania Myśli Reformowanej Horn, 2020.

Kalwin, Jan, O zwierzchności świeckiej, porzadne, według sznuru Pisma świętego opisanie. Zaraz o pożytkach i powinnościach urzędu jej. Z łacińskiego na polskie wiernie przettumaczone: Anonimowy przekład polski dwudziestego rozdziału czwartej księgi 'Institutio Christianae religionis nunc uere demum suo titulo respondens' Jana Kalwina wydany w 1599 r., introduction and ed. Wojciech Kriegseisen, Warsaw: Wydawnictwo Naukowe Semper, 2009.

[Kochlewski, Piotr], 'Pobożnego ewangelika do braciej tegoż wyznania narodu polskiego i litewskiego przestroga i upomnienie, ręką pana Kochlewskiego pisana', in Państwo świeckie czy księże?: Spór o rolę duchowieństwa katolickiego w Rzeczypospolitej wczasach Zygmunta III Wazy: Wybórtekstów, ed. Urszula Augustyniak, Warsaw: Wydawnictwo Naukowe Semper, 2013, pp. 179-233.

Konfesja sandomierska, ed. Krystyna Długosz-Kurczabowa, Warsaw: Wydawnictwo Naukowe Semper, 1995, pp. 53-57. 
Kraiński, Krzysztof, Postylla Kościoła powszechnego apostolskiego słowem bożym ugruntowanego na Jezusie Chrystusie..., part 1-3, Łaszczów, 1611, part 4-5, Łaszczów, 1617.

Lubieniecki, Andrzej, Polonoeutychia, ed. Alina Linda et al., Warsaw and Łódź: Państwowe Wydawnictwo Naukowe, 1982.

Lubieniecki, Stanisław, Historia reformacji polskiej, w której przedstawia się poczatki oraz rozwój zarówno zreformowanych jako też antytrynitarzy w Polsce oraz w ziemiach sasiednich, transl. and ed. Edmund Bursche, Book 1, Rocznik Teologiczny, 3, 1938, pp. 181-281, Book 2, Rocznik Teologiczny, 4, 1939, pp. 1-190.

Lubieniecki, Stanisław, Historia reformationis Polonicae in qua tum reformatorum, tum antitrinitariorum origo et progressus in Polonia et finitimis provinciis narrantur, Amsterdam: [n. pub.], 1685.

Lubieniecki, Stanisław, Historia reformationis Polonicae, pref. Henryk Barycz, Warsaw: Państwowe Wydawnictwo Naukowe, 1971, Biblioteka Pisarzy Reformacyjnych, vol. 9.

Seneca, Lucjusz Anneusz, 'O opatrzności (De Providentia)', in idem, Myśli, bilingual edition, transl. and ed. Stanisław Stabryła, Cracow: Wydawnictwo Literackie, 1987, pp. 36-51.

[Thomas Aquinas] S. Thomae de Aquino, Summa Theologiae, part 1, <http:// corpusthomisticum.org $>$ [accessed 20 May 2020].

[Thomas Aquinas] Św. Tomasz, Summa teologiczna, vol. 2, transl. and ed. Pius Bełch OP, 34 vols, London: Veritas, 1962-86, vol. 2, [1977].

Węgierski, Andrzej, Libri quattuor Slavoniae reformatae, pref. Janusz Tazbir, Warsaw: Państwowe Wydawnictwo Naukowe, 1973, Biblioteka Pisarzy Reformacyjnych vol. 11.

[Węgierski, Andrzej] Adrianus Regenvolscius, Systema historico-chronologicum ecclesiarum Slavonicarum per provincias varias, Utrecht: [n. pub.], 1652.

Witsius, Hermann, De oeconomia foederum Dei cum hominibus libri quatuor, Leeuwarden: [n. pub.], 1677.

Wolan, Andrzej, De libertate politica sive civili libellus lectu non indignus, Cracow: [n. pub.], 1572.

Wolan, Andrzej, De libertate politica sive civili. O wolności Rzeczypospolitej albo ślacheckiej, transl. Stanisław Dubingowicz, ed. Maciej Eder and Roman Mazurkiewicz, sc. ed. Wacław Uruszczak, Warsaw: Wydawnictwo Neriton: 2010.

Wolan, Andrzej, o wolności rzeczypospolitej albo ślacheckiej książka godna ku czytaniu, transl. Stanisław Dubingowicz, Vilnius: [n. pub.], 1606.

[Wolan, Andrzej], Politica. O wolności polski pospolity, transl. Kasper Pepłowski, Poznań: [n. pub.], 1611.

Zawadzki, Kazimierz, Historia arcana, seu annalium polonicorum libri VII. Reductae primum et post Piasti tempora vere liberi voti liberae electionis, centuriatis Regni comitiis in electorali campo celebratae, Frankfurt am Main: [n. pub.], 1699.

Zwingli, Huldrych, 'Ad illustrissimum Cattorum principem Philippum, sermonis de providentia Dei anamnema', in idem, Opera completa editio prima, 8 vols, ed. 
Melchior Schuler and Johannes Schulthess, Zürich: F. Schulthess, 1829-42, vol. 4: Latinorum scriptorum pars secunda, 1841, pp. 79-144.

Zwingli, Huldrych, ‘O Opatrzności Bożej’, transl. Juliusz Domański, in Myśl filozoficzno-religijna Reformacji XVI wieku, ed. Lech Szczucki, Warsaw: Państwowe Wydawnictwo Naukowe, 1972, pp. 106-67.

\section{Literature}

Anderson, Benedict, Imagined Communities: Reflections on the Origin and Spread of Nationalism, London: Verso, 1983.

Asselt, Willem Jan, The Federal Theology of Johannes Cocceius (1603-1669), Leiden: Brill, 2001.

Augustyniak, Urszula, ‘Granice wolności obywatela w XVI-XVII w. Jednostka wobec władzy, prawa i społeczeństwa', in Wolność i jej granice: Polskie dylematy, ed. Jacek Kloczkowski, Cracow: Ośrodek Myśli Politycznej; Wyższa Szkoła Europejska im. ks. J. Tischnera, 2007, pp. 13-37.

Baker, J. Wayne, Heinrich Bullinger and the Covenant: The Other Reformed Tradition, Athens, OH,: Ohio University Press, 1980.

Baker, J. Wayne, 'Heinrich Bullinger, the Covenant, and the Reformed Tradition in Retrospect', Sixteenth Century Journal, 29, 1998, 2, pp. 359-76.

Bargieł, Franciszek, 'Opatrzność Boża a zło według św. Augustyna i św. Tomasza', Rocznik Wydziału Filozoficznego Wyższej Szkoły Filozoficzno-Pedagogicznej 'Ignatianum'w Krakowie, 11, 2004/05, pp. 113-43.

Barry, Patrick J., 'Discourse on Universal History', The Catholic Historical Review, 20, 1934, 3, pp. 260-80.

Bartkiewicz, Kazimierz, Obraz dziejów ojczystych w świadomości historycznej w Polsce doby oświecenia, Lublin: Państwowe Wydawnictwo Naukowe, 1979.

Barycz, Henryk, 'Optymistyczna wizja dziejów narodowych', in idem, Szlakami dziejopisarstwa staropolskiego: Studia nad historiografia w. XVI-XVIII, Wrocław: Zakład Narodowy im. Ossolińskich, 1981, pp. 203-42.

Barycz, Henryk, 'Stanisław Lubieniecki - historyk reformacji polskiej’, in idem, Szlakami dziejopisarstwa staropolskiego, pp. 243-66.

Bečková, Marta, 'Daniel Ernst Jablonski und seine Beziehungen zu Polen', in Daniel Ernst Jablonski: Religion, Wissenschaft und Politik um 1700, ed. Joachim Bahlcke and Werner Korthaase, Wiesbaden: Harrassowitz Verlag, 2008, pp. 206-22, Jabloniana: Quellen und Forschungen zur europäischen Kulturgeschichte der Frühen Neuzeit, vol. 1.

Bem, Kazimierz, 'Wilki i łagodne jagniątka Chrystusa': Powstanie, rozwój i rola Holenderskiego Kościoła Reformowanego w XVI i XVII wieku, Warsaw: Wydawnictwo Naukowe Semper, 2013.

Bierma, Lyle D., 'The Role of Covenant Theology in Early Reformed Orthodoxy', Sixteenth Century Journal, 21, 1990, 3, pp. 453-62.

Blacketer, Raymond A., 'Arminius' concept of Covenant in its historical context', Nederlands archief voor kerkgeschiedenis, 80, 2000, 2, pp. 193-220. 
Bömelburg, Hans-Jürgen, 'Maria als Garantin nationaler Freiheit in Polen: Ein typologischer Sonderfall des Marienpatronats in einer partizipativen Adelsgesellschaft', in Maria in der Krise: Kultpraxis zwischen Konfession und Politik in Ostmitteleuropa, ed. Agnieszka Gąsior, Cologne: Böhlau Verlag, 2014, pp. 79-92, Visuelle Geschichtskultur, vol. 10.

Bömelburg, Hans-Jürgen, Polska myśl historyczna a humanistyczna historia narodowa (1500-1700), transl. Zdzisław Owczarek, introduction Andreas Lawaty, ed. Maciej Ptaszyński, Cracow: Universitas, 2011.

Bracha, Krzysztof, 'Spectabilis - opactrnoszcz: Oczy Pana w nauczaniu kaznodziejskim w Polsce późnego średniowiecza', in Staropolski oglą świata: Sarmacki sensualizm, red. Filip Wolański, Toruń: Wydawnictwo Adam Marszałek, 2017, pp. 11-22.

Brojer, Wojciech, 'Anioł w wyobraźni chrześcijan do XIII wieku', in Wyobraźnia średniowieczna, ed. Teresa Michałowska, Warsaw: Instytut Badań Literackich PAN, 1996, pp. 155-76.

Buczak, Robert, 'Kontrowersje i ponadczasowy wydźwięk legendy "rokoszu gliniańskiego” w sarmackiej wizji dziejów Augustyna Kołudzkiego’, In Gremium: Studia nad historia, kultura i polityka, 2, 2008, pp. 45-59.

Chrzanowski, Tadeusz, 'Sarmacka eschatologia', in idem, Wędrówki po Sarmacji europejskiej: Eseje o sztuce i kulturze staropolskiej, Cracow: Wydawnictwo Znak, 1988, pp. 252-83.

Chrzanowski, Tadeusz, 'Sarmatyzm - mity dawne i współczesne’, in idem, Wędrówki po Sarmacji europejskiej, pp. 7-29.

Coetzee, Callie F.C., 'The Doctrine of Providence in the Institutes of Calvin - Still Relevant?', In die Skriflig/In Luce Verbi, 44, 2010, Supplement 3, pp. 145-66.

Coffey, John, 'The Language of Liberty in Calvinist Political Thought', in Freedom and the Construction of Europe, ed. Quentin Skinner and Martin van Gelderen, 2 vols, Cambridge: Cambridge University Press, 2013, vol. 1: Religious Freedom and Civil Liberty, pp. 296-316.

Cynarski, Stanisław, 'Sarmatyzm - ideologia i styl życia', in Polska XVII wieku: Państwo, społeczeństwo, kultura, ed. Janusz Tazbir, Warsaw: Wiedza Powszechna, 1969, pp. 220-43.

Czarczyński, Piotr, 'Między "święta prawdą" a herezją - Biblia w Wywodzie jedynowładnego państwa świata Wojciecha Dembołęckiego', Tematy i Konteksty, 11, 2016, 6, pp. 125-39.

Czerenkiewicz, Michał, Sarmaci i Opatrzność, Passage to knowledge, Museum of King Jan III's Palace at Wilanów, <https://www.wilanow-palac.pl/prowidencjalizm _sarmatow.html $>$ [accessed 15 May 2020].

Czyż, Renata, Obrona wiary w edycjach postylli Grzegorza z Żarnowca, Warsaw: Wydawnictwo Naukowe Semper, 2008.

Daugirdas, Kęstutis, Andreas Volanus und die Reformation im Grossfürstentum Litauen, Mainz: Verlag Philipp von Zabern, 2008, Veröffentlichungen des Instituts für Europäische Geschichte Mainz, Abteilung für Abendländische Religionsgeschichte, vol. 221. 
Dixon, C. Scott, Protestants: A History from Wittenberg to Pennsylvania 1517-1740, Chichester: Wiley-Blackwell, 2010.

Dolański, Dariusz, Zachód w polskiej myśli historycznej czasów saskich: Nurt sarmacko-teologiczny, Zielona Góra: Uniwersytet Zielonogórski, 2002.

Domański, Juliusz, 'Opatrzność Boża i wolność ludzka w filozofii św. Augustyna', Przegląd Tomistyczny, 10, 2004, pp. 7-32.

Dorocki, Damian, 'Doktryna predestynacji w teologii Jakuba Arminiusza', Teologia i Człowiek: Kwartalnik Wydziału Teologicznego UAM, 35, 2016, 3, pp. 107-24.

Drake, George, 'The Ideology of Oliver Cromwell', Church History, 35, 1966, 3, pp. 259-72.

Filip, Grażyna, and Magdalena Patro-Kucab, 'Obraz sarmatyzmu utrwalony w polskiej leksyce i przestrzeni społecznej - wybrane zagadnienia i przykłady', Słowo: Studia językoznawcze, 4, 2013, pp. 53-71.

Finlayson, Michael, 'Clarendon, Providence and the Historical Revolution', Albion: A Quarterly Journal Concerned with British Studies, 22, 1990, 4, pp. 607-32.

Garrigou-Lagrange OP, Réginald, 'La prédestination d'après les pères latins, particulièrement d'après saint Augustin', in Dictionnaire de Théologie Catholique, ed. Jean M.A. Vacant, Eugène Mangenot and Émile Amann, 15 vols, Paris: Letouzey et Ané, 1902-50, vol. 12, part 2, 1935, cols 2832-2901, <http://jesusmarie.free .fr/dictionnaire_de_theologie_catholique.html $\rangle$ [accessed 17 March 2021].

Garrigou-Lagrange OP Réginald, 'La providence selon la théologie', in Dictionnaire de Théologie Catholique, vol. 13, part 1, 1936, cols 985-1023, <http://jesusmarie .free.fr/dictionnaire_de_theologie_catholique.html $\rangle$ [accessed 17 March 2021]. Górski, Karol, 'Religijność sarmatyzmu a kwietyzm', Teksty: Teoria literatury, krytyka, interpretacja, 16, 1974, 4, pp. 58-75.

Greaves, Richard L., 'The Origins and Early Development of English Covenant Theology', The Historian, 31, 1968, 1, pp. 21-35.

Grzybowski, Stanisław, 'Z dziejów popularyzacji nauki w czasach saskich: Spóźniona synteza księdza Szymona Majchrowicza', in Studia i Materiały z Dziejów Nauki Polskiej, ser. A, no. 7, 1965, pp. 133-45.

Hanusiewicz-Lavallee, Małgorzata, 'Dawne i nowe: Tożsamość wyznaniowa katolików świeckich w potrydenckiej Rzeczypospolitej’, in Formowanie kultury katolickiej $w$ dobie potrydenckiej: Powszechność i narodowość katolicyzmu polskiego, ed. Joanna Dąbkowska-Kujko, Warsaw: Wydawnictwo Uniwersytetu Warszawskiego, 2016, pp. 103-44.

Helm, Paul, 'Calvin (and Zwingli) on Divine Providence', Calvin Theological Journal, 29, 1994, 2, pp. 388-405.

Hesselink, I. John, 'Calvin's Theology', in The Cambridge Companion to John Calvin, ed. Donald K. McKim, Cambridge: Cambridge University Press, 2006, pp. 74-92.

The Invention of Tradition, ed. Eric Hobsbawm and Terence Ranger, Cambridge: Cambridge University Press, 1983.

Jasiński, Maciej, Stanisław Lubieniecki i astronomia kometarna XVII stulecia, Warsaw: Oficyna Wydawnicza Aspra, 2017. 
Jedin, Herbert, 'Vorsehung', in Lexikon für Theologie und Kirche, 10 vols, ed. Michael Buchberger, Freiburg im Breisgau: Verlag Herder, 1930-38, vol. 10, 1938.

Jędraszewski, Marek, 'Opatrzność Boża w świetle filozofii', Studia Theologica Varsaviensia, 48, 2010, 2, pp. 63-91.

Jelińska, Joanna, 'Sarmacki' wizerunek szlachcica-ewangelika w Postylli Krzysztofa Kraińskiego, Warsaw: Wydawnictwo Naukowe Semper, 1995, Studia i Materiały Wydawnictwa Naukowego Semper, vol. 2.

Kempfi, Andrzej, 'Frycz a Wolan: Zapomniana karta recepcji Frycza w Polsce', in Andrzej Frycz Modrzewski a problemy kultury polskiego Odrodzenia, ed. Tadeusz Bieńkowski, Wrocław: Zakład Narodowy im. Ossolińskich; Warsaw: Wydawnictwo Polskiej Akademii Nauk, 1974, pp. 203-18.

Kiedroń, Stefan, 'Jan Makowski (1588-1644): Polski teolog we fryzyjskim Franekerze', OiRP, 40, 1996, pp. 37-51.

Komorowska, Magdalena, 'Kształt edytorski postylli polskich XVI i XVII wieku w poszukiwaniu staropolskich konwencji wydawniczych', Terminus, 17, 2015, 3(34), pp. 317-67.

Kopaliński, Władysław, Słownik mitów i tradycji kultury, Warsaw: Państwowy Instytut Wydawniczy, 1996.

Kot, Stanisław, 'Polska złotego wieku wobec kultury zachodniej’, in idem, Polska złotego wieku a Europa: Studia i szkice, ed. Henryk Barycz, Warsaw: Państwowy Instytut Wydawniczy, 1987, pp. 122-95.

Kowalska, Halina, 'Grzegorz z Żarnowca', in PSB, vol. 9, ed. Kazimierz Lepszy et al., Wrocław, Cracow and Warsaw: Zakład Narodowy im. Ossolińskich; Wydawnictwo Polskiej Akademii Nauk, 1960-61, pp. 91-93.

Krawczyk, Antoni, Historiografia krytyczna: Formowanie się nowożytnej postawy naukowej w polskim piśmiennictwie historycznym XVII wieku, Lublin: Wydawnictwo Uniwersytetu Marii Curie-Skłodowskiej, 1994.

Krawczyk, Antoni, 'Historiozoficzna wizja procesu dziejowego w Poloneutychii Andrzeja Lubienieckiego’, Res Historica, 10: Z dziejów stosunków wyznaniowych w Rzeczypospolitej XVI-XVII wieku: Materiały konferencji naukowej 'Jan Niemojewski - polska reformacja - przełom stuleci', Lublin 26-27 listopada 1998 roku, ed. Henryk Gmiterek. 2000, pp. 119-39.

Kriegseisen, Wojciech, Ewangelicy polscy i litewscy w epoce saskiej (1696-1763): Sytuacja prawna, organizacja i stosunki międzywyznaniowe, Warsaw: Wydawnictwo Naukowe Semper, 1996.

Kyle, Richard, 'John Knox's Concept of Divine Providence and Its Influence on His Thought', Albion: A Quarterly Journal Concerned with British Studies, 18, 1986, 3, pp. 395-410.

Leszczyński, Rafał Marcin, ‘Cyceroniańskie wątki w Institutio Christianae religionis Jana Kalwina', in idem, Jan Kalwin: Studia nad myśla Reformatora, Warsaw: Pismo społeczno-religijne 'Jednota', 2017, pp. 29-61.

Leszczyński, Rafał Marcin, Starożytna koncepcja Logosu i jej wpływ na myśl wczesnego chrześcijaństwa, Warsaw, Wydawnictwo Naukowe Semper, 2004. 
Leszczyński, Rafał Marcin, 'Ulrych Zwingli a filozofia', Rocznik Teologiczny, 62, 2020, 2, pp. 463-90.

Levering, Matthew, 'Eternity, History, and Divine Providence', Angelicum, 88, 2011, 2, pp. 403-23.

Łucki, Aleksander, 'Wstęp', in Wincenty Pol, Mohort, introduction and ed. Aleksander Łucki, Cracow: Krakowska Spółka Wydawnicza, 1925, pp. III-XXXIV, Biblioteka Narodowa, ser. 1, vol. 52.

Maciuszko, Janusz T., Ewangelicka postyllografia polska XVI-XVIII wieku: Charakterystyka - analiza porównawcza - recepcja, Warsaw: Chrześcijańska Akademia Teologiczna, 1987.

Manikowski, Adam, 'Czy siedemnastowieczna Rzeczpospolita była anomalią wśród innych państw europejskich?', OiRP, 37, 1993, pp. 79-87.

Mańkowski, Tadeusz, Genealogia sarmatyzmu, Warsaw: Towarzystwo Wydawnicze "Łuk", 1946.

Markiewicz, Mariusz, “'Jedyna i nieporównywalna?”: Normalne państwo europejskie, czy może państwo pogranicza?', in Między Zachodem a Wschodem: Studia z dziejów Rzeczypospolitej w epoce nowożytnej, ed.Jacek Staszewski, Krzysztof Mikulski and Jarosław Dumanowski, Toruń: Wydawnictwo Adam Marszałek, 2002, pp. 17-22.

McCann, Hugh J., and Daniel M. Johnson, 'Divine Providence', in The Stanford Encyclopedia of Philosophy, ed. Edward N. Zalta, 〈https://plato.stanford.edu/archives/ spr2017/entries/providence-divine/ $>$ [accessed 16 May 2020].

Niedźwiedź, Jakub, 'Sarmatyzm, czyli tradycja wynaleziona', Teksty Drugie, 2015, 1, pp. 46-42.

Obremski, Krzysztof, 'Sarmacki mesjanizm', Ogród: Kwartalnik, 7, 1994, 4, pp. 119-30.

Ogonowski, Zbigniew, 'Z dziejów megalomanii narodowej', in idem, Filozofia polityczna w Polsce XVII wieku i tradycje demokracji europejskiej, Warsaw: Instytut Filozofii i Socjologiii PAN, 1992, pp. 157-73.

Randall, David, 'Providence, Fortune, and the Experience of Combat: English Printed Battlefield Reports, Circa 1570-1637', Sixteenth Century Journal, 35, 2004, 4, pp. 1053-77.

Rascol, Annette, 'La providence selon saint Augustin', in Dictionnaire de Théologie Catholique, ed. Jean M.A. Vacant, Eugène Mangenot and Émile Amann, 15 vols, Paris: Letouzey et Ané, 1902-50, vol. 13, part 1, 1936, cols 961-84, 〈http://jesusmarie.free.fr/dictionnaire_de_theologie_catholique.html > [accessed 17 March 2021].

Słownik sarmatyzmu: Idee, pojęcia, symbole, ed. Andrzej Borowski, Cracow: Wydawnictwo Literackie, 2001.

Ślusarczyk, Piotr Sebastian, 'Między traktatem historycznym a publicystyką: Studium o Trwałości szczęśliwej królestw Szymona Majchrowicza', doctoral dissertation, supervisor Roman Krzywy, Institute of Polish Literature, Faculty of Polish Studies, University of Warsaw, 2013, 〈http://depotuw.ceon.pl〉 [accessed 17 May 2020]. 
Stępień, Tomasz, 'Filozoficzne podstawy rozumienia opatrzności u greckich Ojców Kościoła', Warszawskie Studia Teologiczne, 14, 2001, pp. 97-114.

Szkadłubowicz, Kazimierz, 'Kilka szczegółów z życia Krzysztofa Kraińskiego', in Studia z dziejów kultury polskiej: Książa zbiorowa, ed. Henryk Barycz and Jan Hulewicz, Warsaw: Gebethner i Wolff, 1948.

Sztyber, Radosław, 'Skądże to zbłaźnienie świata?’: Wojciecha Dembołęckiego ‘Wywód jedynowładnego państwa świata’ (studium monograficzne i edycja krytyczna dzieła), Zielona Góra: Oficyna Wydawnicza Uniwersytety Zielonogórskiego, 2012.

Szwargocka, Katarzyna Wiktoria, 'Sarmacka Bogini': Kult maryjny w Polsce doby baroku, Torun: Wydawnictwo Adam Marszałek, 2010.

Talarowski, Adam, 'Dzieje w rękach Opatrzności: Elementy historiozofii Jana Długosza i jej uwarunkowania', RH, 84, 2018, pp. 191-225.

Tazbir, Janusz, 'Andrzej Węgierski - historyk słowiańskiej reformacji', in Ars Historica: Prace z historii dziejów powszechnych i Polski, ed. Marian Biskup et al., Poznań: Wydawnictwo Naukowe UAM, 1976, pp. 603-16.

Tazbir, Janusz, “"Kopalnia najciekawszych szczegółów...” (Postylla Krzysztofa Kraińskiego)', OiRP, 28, 1983, pp. 195-231.

Tazbir, Janusz, 'Kraiński Krzysztof', in PSB, vol. 15, ed. Bogusław Leśnodorski et al., Wrocław, Warsaw and Cracow: Zakład Narodowy im. Ossolińskich; Wydawnictwo Polskiej Akademii Nauk, 1970, pp. 92-93.

Tazbir, Janusz, 'Lubieniecki Andrzej starszy', in PSB, vol. 17, ed. Bogusław Leśnodorski et al., Wrocław: Zakład Narodowy im. Ossolińskich; Wydawnictwo Polskiej Akademii Nauk, 1972, pp. 594-96.

Tazbir, Janusz, 'Lubieniecki Stanisław młodszy', in PSB, vol. 17, pp. 603-07.

Tazbir, Janusz, Polska przedmurzem Europy, Warsaw: Twój Styl, 2004.

Tazbir, Janusz, 'Problemy wyznaniowe', in Polska XVII wieku: Państwo, społeczeństwo, kultura, ed. Janusz Tazbir, Warsaw: Wiedza Powszechna, 1969, pp. 189-219.

Tazbir,Janusz, 'Religijność doby kontrreformacji', in idem, Szlachta iteologowie: Studia z dziejów polskiej kontrreformacji, Warsaw: Wiedza Powszechna, 1987, pp. 217-29.

Tazbir, Janusz, 'Sarmatyzacja katolicyzmu w XVII wieku', in Wiek XVII - kontrreformacja - barok: Prace z historii kultury, ed. Jerzy Pelc, Wrocław: Zakład Narodowy im. Ossolińskich, 1970, pp. 7-37.

Tazbir, Janusz, 'Sarmatyzm a barok', KH, 76, 1969, 4, pp. 815-30.

Tazbir, Janusz, Stando lubentius moriar: Biografia Stanisława Lubienieckiego, Warsaw: Iskry, 2003.

Tazbir, Janusz, ‘Wizje przyszłości w kulturze staropolskiej’, OiRP, 27, 1982, pp. 107-41.

Tazbir, Janusz, 'Ze studiów nad ksenofobią w Polsce w dobie późnego renesansu', PH, 48, 1957, 4, pp. 655-82.

Tradycja wynaleziona, ed. Eric Hobsbawm and Terence Ranger, transl. Mieczysław Godyń and Filip Godyń, Cracow: Wydawnictwo Uniwersytetu Jagiellońskiego, 2008.

Tricoire, Damien, ‘Gottesmutter Königin von Polen: Die Sakralisierung der polnischen Monarchie im Vergleich mit Frankreich und Bayern (1630er-1650er 
Jahre)', in Maria in der Krise: Kultpraxis zwischen Konfession und Politik in Ostmitteleuropa, ed. Agnieszka Gąsior, Cologne: Böhlau Verlag, 2014, pp. 93-116, Visuelle Geschichtskultur, vol. 10.

Tricoire, Damien, La Vierge et le Roi: Politique princière et imaginaire catholique dans l'Europe du XVII siècle, Paris:, Presses Universitaires de Paris-Sorbonne, 2017.

Tworek, Stanisław, 'Starania o ujednolicenie obrządku kalwińskiego w Polsce XVII w.', OiRP, 16, 1971, pp. 117-39.

Tygielski, Wojciech, 'Rzeczpospolita szlachecka: paradoks historii czy europejska norma?', in Tematy polsko-białoruskie: Historia. Literatura. Edukacja, ed. Robert Traba, Olsztyn: Wspólnota Kulturowa Borussia, 2003, pp. 40-53.

Ujejski, Józef, Dzieje polskiego mesjanizmu do powstania listopadowego włącznie, Lviv: Zakład Narodowy im. Ossolińskich, 1931.

Ulewicz, Tadeusz, Sarmacja: Studium z problematyki słowiańskiej XV i XVI w., Cracow: Wydawnictwo Studium Słowiańskiego Uniwersytetu Jagiellońskiego, 1950.

Ulewicz, Tadeusz, Sarmacja: Studium z problematyki słowiańskiej XV i XVI w.: Zagadnienia sarmatyzmu w kulturze i literaturze polskiej (problematyka ogólna i zarys historyczny), Cracow: Collegium Columbinum, 2006, Biblioteka Tradycji, vol. 46.

Urban, Wacław, 'Epitalamia i epitafia pastorskiej rodziny Węgierskich w XVII w.', in Wesela, chrzciny i pogrzeby w XVI-XVIII wieku: Kultura życia i śmierci, ed. Henryk Suchojad, Warsaw: Wydawnictwo Naukowe Semper, 2001, pp. 167-72.

Urban, Wacław, 'Rola braci Węgierskich w podtrzymywaniu protestantyzmu polskiego', in Religia, edukacja, kultura: Księga pamiatkowa dedykowana Profesorowi Stanisławowi Litakowi, ed. Marian Surdacki, Lublin: Towarzystwo Naukowe KUL, 2002, pp. 47-51.

VanderMolen, Ronald J., 'Providence as Mystery, Providence as Revelation: Puritan and Anglican Modifications of John Calvin's Doctrine of Providence', Church History, 47, 1978, 1, pp. 27-47.

Visser, Derk, 'The Covenant in Zacharias Ursinus', Sixteenth Century Journal, 18, 1987, 4, pp. 513-44.

Vos, Anotonie, 'Reformed Orthodoxy in the Netherlands', in A Companion to Reformed Orthodoxy, ed. Herman Selderhuis, Leiden: Brill, 2013, pp. 119-76.

Walsham, Alexandra, 'History, Memory, and the English Reformation', HJ, 55, 2012, 4, pp. 899-938.

Walsham, Alexandra, Providence in Early Modern England, Oxford: Clarendon Press, 1999.

Wdowik, Agata, 'Poszukiwania własnych korzeni - rzecz o tekstach Krzysztofa Koehlera (oraz Andrzeja Waśki)', in Nowoczesność i sarmatyzm, ed. Przemysław Czapliński, Poznań: Wydawnictwo 'Poznańskie Studia Polonistyczne', 2011, pp. 231-50.

Winship, Michael P., Seers of God: Puritan Providentialism in the Restoration and Early Enlightenment, Baltimore, MD: John Hopkins University Press, 1996.

Worden, Blair, 'Providence and Politics in Cromwellian England', P\&P, 109, 1985, pp. 55-99. 
Ziemba, Antoni, Nowe dzieci Izraela: Stary Testament w kulturze holenderskiej XVII wieku, Warsaw: Neriton, 2000.

Zybała, Andrzej, 'Wokół kultury umysłowej w Polsce - jej źródła i przejawy', Kultura i Społeczeństwo, 2017, 4, pp. 101-21.

Bi og r a phy: Prof. dr hab. Wojciech Kriegseisen - Chair of the Department of Early Modern History, Tadeusz Manteuffel Institute of History, Polish Academy of Sciences. He researches confessional relations in the Polish-Lithuanian Commonwealth in the sixteenth-eighteenth centuries; the religious and political culture of Polish and Lithuanian non-Catholics in the period; as well as relations between religious communities and governments in early modern Europe. Editor of the Odrodzenie i Reformacja w Polsce annual journal. 